University of Rhode Island

DigitalCommons@URI

Open Access Master's Theses

1980

\title{
Correlation of In Vitro Chemotaxis with In Vitro Virulence of Bacteroides Fragilis Products
}

Stephen Atsekhagbo Adamu

University of Rhode Island

Follow this and additional works at: https://digitalcommons.uri.edu/theses

\section{Recommended Citation}

Adamu, Stephen Atsekhagbo, "Correlation of In Vitro Chemotaxis with In Vitro Virulence of Bacteroides Fragilis Products" (1980). Open Access Master's Theses. Paper 826.

https://digitalcommons.uri.edu/theses/826

This Thesis is brought to you for free and open access by DigitalCommons@URI. It has been accepted for inclusion in Open Access Master's Theses by an authorized administrator of DigitalCommons@URI. For more information, please contact digitalcommons-group@uri.edu. 


\section{CORRELATION OF IN VITRO CHEMOTAXIS \\ WITH IN VIVO VIRULENCE OF \\ BACTEROIDES FRAGILIS PRODUCTS \\ BY \\ STEPHEN ATSEKHAGBO ADAMU}

A THESIS SUBMITTED IN PARTIAL FULFILLMENT OF THE REQUIREMENTS FOR THE DEGREE OF MASTERS OF SCIENCE

IN

MICROBIOLOGY 
MASTER OF SCIENCE THESIS

OF

STEPHEN ATSEKHAGBO ADAMU

Approved:

Thes is Committee

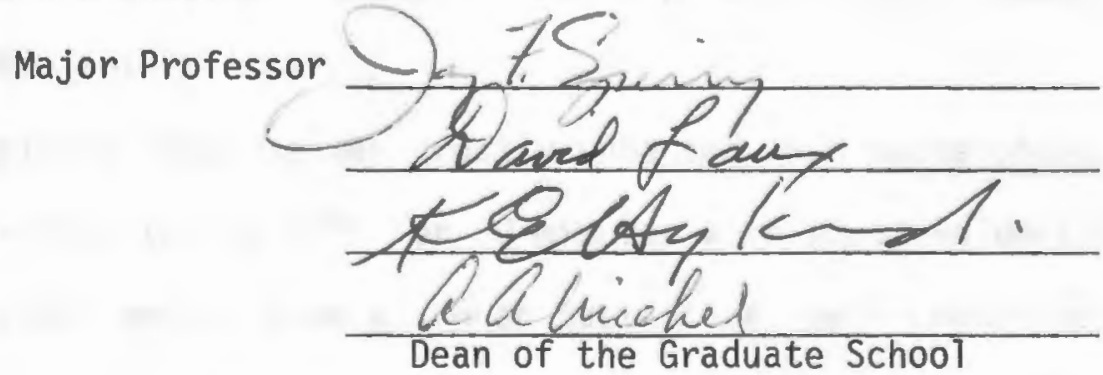

UNIVERSITY OF RHODE ISLAND 


\section{ABSTRACT}

A possible mechanism of pathogenicity of Bacteroides fragilis was determined while studying the interaction of rabbit peritoneal polymorphonuclear neutrophils (PMN neutrophils) with Bacteroides products (outer membrane and culture supernatant of $\underline{B}$. fragilis VPI 9032, VPI 2553 and $\underline{B}$. vulgatus VPI 4245; culture supernatant of $\underline{B}$. thetaiotaomicron VPI 5482; and LPS of B. fragilis VPI 9032). Neutrophils were elicited by injection of glycogen into the peritoneal cavity of rabbits and harvested four to seven hours later.

When rabbit peritoneal neutrophils were exposed to Bacteroides products, the neutrophils released $\mathrm{N}$-acety $\mathrm{T}-\mathrm{B}$-glucosaminidase, a 1ysosomal enzyme. Bacteroides products also induced directional 1ocomotion (chemotaxis) of rabbit PMN neutrophils in Boyden chambers. The chemotactic response of rabbit neutrophils was dependent on the dosage of Bacteroides stimulant.

The enzyme release response was greatly enhanced when Bacteroides products were pre-incubated at $37^{\circ} \mathrm{C}$ for 30 minutes with equal volumes of fresh guinea pig complement. However, when Bacteroides outer membrane or sterile culture supernatants were pre-incubated with fresh guinea pig complement, PMN neutrophil chemotaxis was retarded.

Lactate dehydrogenase (a cytoplasmic marker) was not released upon exposure of rabbit PIN neutrophiis to Bacteroides products. This indicated that the response to Bacteroides products reflect an active extracellular secretion of PMN neutrophil lysosomal contents rather than 
a non-specific discharge of enzymes as a result of cell (PMN neutrophil) death.

These findings suggest an altered inflammatory response of neutrophils during the interaction of Bacteroides with the host defense mechanism. 


\section{DEDICATION \\ To my family}




\section{ACKNOWLEDGMENTS}

I would like to express my appreciation to Dr. Jay Sperry for his criticisms and advice, for which I am grateful, and most of all for his encouragement when my authorship seemed to be faltering.

I owe much to Dr. Donald L. Kruetzer of the University of Connecticut Health Center, Farmington, Connecticut, who supplied some reagents and chemotaxis chambers used in this study; his practical assistance was indespensable.

I also would like to thank members of my thesis committee, Dr. David Laux and Dr. Kerwin Hyland for their assistance.

Finally I acknowledge with deep appreciation the loving support and understanding of my wife, Ms. Jacque', and daughter, 0la' Tokumbo who made writing this manuscript at home possible. 


\section{TABLE OF CONTENTS}

\section{$\underline{\text { Page }}$}

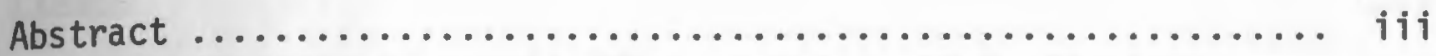

Acknowledgments $\ldots \ldots \ldots \ldots \ldots \ldots \ldots \ldots \ldots \ldots \ldots \ldots \ldots \ldots \ldots \ldots \ldots$ vi

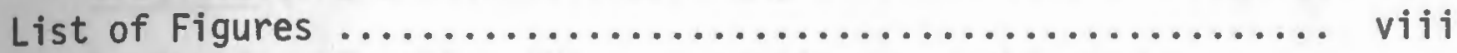

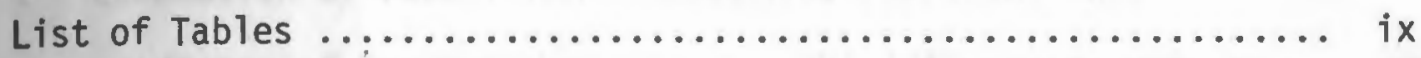

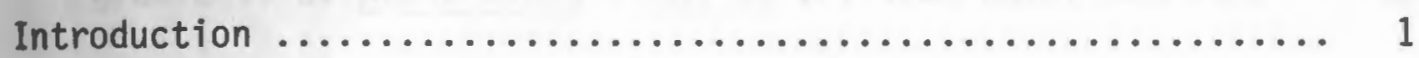

Literature Review ............................... 4

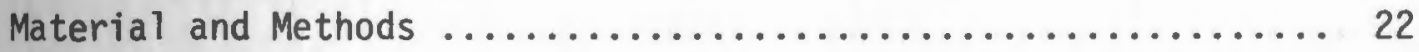

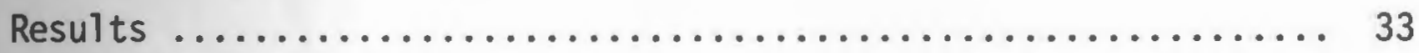

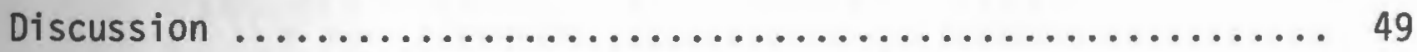

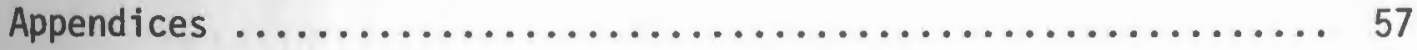

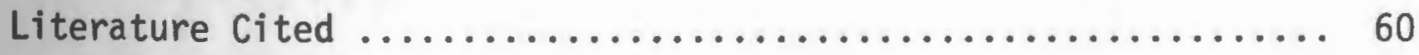




\section{LIST OF FIGURES}

FIGURE

PAGE

1 Dose response of rabbit PMN neutrophils to Bacteroides

fragilis (VPI 5383) outer membrane $\ldots \ldots \ldots \ldots \ldots \ldots \ldots \ldots \ldots, 36$

2 Locomotion of rabbit PMN neutrophils in established

gradients of Bacteroides vulgatus VPI 4245 outer membrane ... 38 


\section{LIST OF TABLES}

TABLE

PAGE

1 Chemotactic response of rabbit PMN neutrophils to the defined medium of Varel and Bryant................. 37

2 Rabbit PMN neutrophils response to Bacteroides fragilis cellular components or products in the presence and absence of guinea pig complement......... 39

3 Rabbit PMN neutrophils chemotactic response to C5 fragment in the presence and absence of Bacteroides fragilis VPI 4383 cellular components

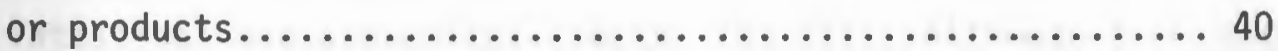

4 N-acety1-B-glucosaminidase activity released from cytochalasin B-treated rabbit PMN neutrophils in response to cellular components or products of Bacteroides

5 N-acetyl-B-glucosaminidase activity released from cytochalas in B-treated rabbit PMN neutrophils in response to Bacteroides cellular products or components pre-incubated at $37^{\circ} \mathrm{C}$ with guinea pig complement for 30 minutes. 


\section{INTRODUCTION}

In recent years increasing emphasis has been placed on the role of obligately anaerobic microorganisms as the etiological agents of many human diseases. Bacteroides is the most common anaerobic organism isolated from bacteremia, intra-abdominal infections, and female genital tract infections $(29,39-44,53,62,63,71)$. Bacteroides fragi 1 is attracts the most concern among the anaerobic non-sporing gram negative bacteria because it has been the most frequent clinical isolate (39-44, 71). Bacteroides fragilis constitutes $60 \%$ of the strains of Bacteroides isolated from blood cultures, lung abscesses, soft tissues, infections of the intestinal and urogenital tracts $(29,71)$. Although $\underline{B}$. vulgatus and $\underline{B}$. thetaiotaomicron are the most frequent fecal isolates and outnumber $\underline{B}$. fragilis in the large intestine of man (41); $\underline{B}$. fragilis is the predominant in intra-abdominal sepsis $(29,44,62)$. B. fragilis is unique because of its resistance to the $\beta$-lactam antibiotics (e.g. penicillin and cephatosporin) $(44,53)$.

Common predisposing factors for $\underline{B}$. fragilis infections are trauma (including surgery, perforating injuries, deliveries and abortions), vascular defects of the mucosal surfaces, systemic conditions such as diabetes melitus, leukemia, alcoholism, malignancy and immunosuppressive therapy which alter resistance to microbial invasion. Earlier views that anaerobes were present in infectious processes as microbial commensals with no role in the septic processes have been disproved by many studies $(29,39-44,71)$. 
Despite increased awareness of the importance of Bacteroides in infectious processes, relatively little information is available regarding specific humoral and cellular host defense mechanisms against these gram negative non-sporing anaerobic microorganisms $(10,63)$ or the mechanism responsible for their pathogenicity $(29,61,71)$.

However, some studies have been done on the interactions between Bacteroides fragilis lipopolysaccharide and PMN neutrophils during inflammation $(77,78)$. An inflammatory response results from any injury to the tissue (e.g. following a mechanical injury or establishment and multiplication of microorganisms). The inflammatory response is a major mechanism used by the mammaliam immune system to destroy potentially toxic materials (59). Generally, inflammatory infiltrates are predominantly PMN neutrophils (30). The accumulation of PMN neutrophils is of major importance to the host, since these neutrophils are intimately involved in the host defense against microbial invasion and in certain inflammatory disease states the neutrophils appear to be responsible for a large degree of the host-tissue destruction (as in acute necrotizing gingivitis) $(73,76,79,80,89)$.

The importance of complement in generating neutrophil chemotactic activity in serum reacted with immune complexes (antigen-antibody complexes) was first demonstrated by Boyden in 1962 (14). More recently, Ward and others $(85,87,90)$, have shown that serum complement is involved in opsonization, phagocytosis, vascular changes of acute inflammation and in amplifying the accumulation of phagocytes (neutrophils) at sites of chronic inflammation. 
Phagocytosis and intracellular killing of microorganisms is a primary protective function of PMN neutrophils $(10,12,14,73)$. Bacteria produce soluble, diffusable materials (factors) detectable by PMN neutrophils some distance away (81). The PMN neutrophils unidirectionally migrate in the chemical gradient toward the source of the attractant. Polymorphonuclear neutrophils contain a wide variety of hydrolytic enzymes and substances which are directly responsible for the killing and digestion of bacteria and other engulfed particles $(2,4,49,50)$.

Once at the inflammatory site, neutrophils also may release enzymes that intensify the influx of additional neutrophils as well as modulate the influx of mononuclear cells (89). The early local accumulation of these neutrophils at the sites of microbial invasion should aid in the rapid destruction of microorganisms and in healing of wounds. On the other hand, factors that delay or inhibit this early PMN neutrophil accumulation such as neutropenia, endotoxin (73), adrenalin administration or anti-inflammatory drugs, would allow for proliferation and probable dissemination of microorganisms in the host.

The objective of this research was to investigate a potential mechanism of pathogenicity of Bacteroides fragilis by correlating in vitro chemotaxis of, and enzyme release by PMN neutrophils in response to Bacteroides fragilis, with in vivo virulence. The interactions of Bacteroides products [sterile culture fi]trates (bacterial factors), outer membrane, and lipopolysaccharide] with PMN neutrophils which constitute the first line of the defense mechanism were determined and evidence was provided to support the hypothesis concerning the nature of the initial host response following contamination with $\underline{B}$. fragilis. 


\section{LITERATURE REVIEW}

Polymorphonuclear (PMN) neutrophil responses to serum complementderived chemotactic factors, synthetic peptides and bacterial chemotactic factors have been investigated for a number of years $(32,46,70$, 84); however, a clear relationship between these factors and PMN neutrophils is yet to be defined. The majority of this work has been done with complement-derived chemotactic factors and synthetic peptides and little is known about chemotactic factors produced by bacteria.

\section{Infectious Microorganisms and Chemotaxis}

Although many pyogenic bacteria produce factors chemotactic for neutrophils, little or nothing has been done to purify or identify these chemotactic factors. Keller and Sorkin showed that culture filtrates of Staphylococcus aureus and Escherichia coli were chemotactic for PMN neutrophils $(46,47)$; but they did not purify or identify the active components nor did they determine whether any difference existed between these two preparations. Ward, Lepow and Newman examined several bacteria isolated from human infections (91). They demonstrated that sterile culture filtrates from $\underline{S}$. aureus, $\alpha$-hemolytic streptococci, Sreptococcus pneumoniae, E. coli, Proteus mirabilis, Proteus rettgeri and Hafnia species contained substances chemotactic for PMN neutrophils. Again these factors went essentially uncharacterized, except for a chemotactic factor produced by $\underline{S}$. pneumoniae. The pneumococcal factor was described as heat-stable and non-dialyzable (91). 
Besides producing factors chemotactic for neutrophils, bacteria also produce inhibitors of chemotaxis. Bacterial toxins produced by S. aureus and Clostridium perfringens inhibit neutrophil chemotaxis $(93,96)$. Weksler and Hill examined the effects of staphylococcal mucopeptide on the acute inflammatory response by evaluating its effects upon migration of PMN neutrophils (93). They showed that mucopeptide from a virulent strain of $\underline{S}$. aureus, NCTC 9787, but not NCTC 7121 which was less virulent, inhibited the migration of PMN neutrophils toward a chemotactic stimulus in a Boyden Chamber (93). Virulent strains not only inhibit in vitro chemotaxis, but also enhance in vivo mouse virulence in experimental infections. Hill previously demonstrated that mucopeptide from a mouse-virulent strain of $\underline{s}$. aureus inhibited early edema and permitted lesion formation (93).

\section{Anaerobic Gram Negative Bacterial Products}

Kasper and Onderdonk have demonstrated that Bacteroides fragilis, an anaerobic, non-motile, gram negative bacillus has a cell wall similar to most gram negative bacteria $(39-44,62,63)$. The outer membrane complex of $\underline{B}$. fragilis contains a protein-lipid bi-layer with two polysaccharide components. One of the polysaccharide components, the lipopolysaccharide (endotoxin) was immunochemically and biologically identical to the lipopolysaccharide (LPS) extracted by the phenol-water technique $(38,40)$. The two polysaccharides were described as sharing hexose, hexosamine and methy]-pentoses.

Hofstad and Kristoferson reported that LPS from B. fragilis NCTC 9343, extracted by hot water-phenol lacked 2-keto-3-deoxyoctonate (KDO) and heptose, essential components of the inner core of most bacterial 
LPS (37). The biologically active component of LPS is the KDO/lipid A region and the serological specificity of the glycolipid of the LPS is determined by the sugar residues attached to KDO (67).

The LPS of gram negative bacteria contributes to virulence by inhibition of phagocytosis and by direct toxic effects (62). However, the LPS of $\underline{B}$. fragilis differs from other gram negative bacteria, since it basically lacks toxicity $(39-44,62)$.

Bacteroides LPS induces PMN neutrophil chemotaxis in vivo and in vitro through the activation of complement $(46,77)$. Sveen et al showed that Bacteroides LPS was consistently less cytotaxigenic than the reference endotoxin (Salmonella LPS), Fusobacterium LPS and LPS from Veillonella $(77,78)$.

Muschel suggested that the presence of a capsular polysaccharide may be responsible for the resistance of the organism to the bactericidal activity of the complement-antibody system (39). Subsequent observations by Kasper et al that $\underline{B}$. fragilis is encapsulated while other species of Bacteroides are not, focused attention on the capsule of $\underline{B}$. fragilis as a major virulence factor $(38,39,42)$. Kasper, Onderdonk and others demonstrated that the "capsular polysaccharide of $\underline{B}$. fragilis was not an absolute requirement for abscess formation" in their rat experimental model even though "its presence correlated well with the percentage of recipients of abscesses" (62).

The report of Lindberg et al differed from that of Kasper demonstrating that only $77 \%$ of $\underline{B}$. fragilis and that $17 \%$ of $\underline{B}$. ovatus, B. distasonis, B. vulgatus, $\underline{B}$. uniformis and $\underline{B}$. thetajotaomicron isolated from clinical infections were encapsulated (53). The fact that an 
antibody response to the capsular polysaccharide of $\underline{B}$. fragilis has been demonstrated (42) further supports the pathogenic potential of an encapsulated Bacteroides. However, the outer membrane complex of Bacteroides is probably the best candidate for studying the virulence of Bacteroides (43). The outer membrane contains the most important immunologic antigens, and because of its location, the outer membrane is most readily accessible to the host defense mechanisms $(43,62)$.

\section{Classes of Neutrophil Chemotactic Factors}

Bacteria elaborate chemotactic factors in two ways:

(i) they release small peptides of approximately 1,000 molecular weight or larger (85) during bacterial replication $(81,85)$. These substances which directly stimulate directional migration of leukocytes are thought to attach to a site on the responding cell $(46,85,96)$. These chemotactic factors have been named "cytotaxins" by Keller and Sorkin (46).

(ii) they release enzymatic materials which cleave specific components of serum complement (third or fifth complement components) into chemotactically active fragments ( $C 5 f r$ and $(3 f r)$. These substances which have been named "cytotaxigens" (46), lack the ability to directly stimulate locomotion in responding cells. Cytotaxigens unmask the presence of chemotactic mediators in serum resulting in the release of endogenous cytotaxins $(12,46)$.

Harris, using time-lapse photography, provided strong evidence that bacteria elaborate factors chemotactic for neutrophils. He reported 
that neutrophils in suspension moved about randomly; but, cells placed in the presence of bacteria moved unidirectionally toward a bacterium or its $\operatorname{product}(s)(91)$.

\section{Endogenous Complement Chemotactic Factors}

Complement is a series of nine proteins and is involved in several enzyme cascades in plasma. These cascades include, the coagulation system, the kinin system and the properdin system (92). During activation of complement and properdin, products are elaborated which: mediate changes in vascular permeability, attract PMN neutrophils and mononuclear cells, influence the release of lysosomal enzymes, enhance phagocytosis by promoting adherence of complement-coated complexes to formed elements in the blood (immune adherence) and damage cell membranes to induce osmotic lysis and cell death $(25,85,92)$.

Snyderman et al have demonstrated that $\mathrm{C5fr}(\mathrm{C5a})$ is the major chemotactically active complement fragment derived through cleavage of complement by immune complexes $(72,73)$. They have also reported that interaction of endotoxin (LPS) with guinea pig complement ( $\left.C^{\prime}\right)$ in vitro generated a low molecular weight chemotactic factor derived from C'5 $(72,73)$. Trypsin $(73,91)$, cobra venom factor $(72,92)$, virus infected cells $(25,95)$, streptococcal protease $(89)$, and gram negative bacterial protease $(25,60,86)$ also have neutrophil cytotaxigenic activity. Ward and Hill identified the lysosomal protease isolated from rabbit neutrophils and showed that this protease could cleave human C'5 into chemotactic fragments of variable molecular weights (89).

Ward, Cochrane and Muller-Eberhard reported that $C \overline{567}$, a heatstable factor, was chemotactic for neutrophils $(81,88)$. 
C'3 fragment (C3a), a peptide, was also shown to be chemotactic (84) and anaphylatoxic (96). It is cleaved from C' 3 by the action of plasmin $(84,91)$, trypsin (99), tissue protease (90) and gram negative bacterial protease $(84,86,96)$.

Other proteins and some polysaccharides, for example peptone medium (46) and glycogen $(9,46,73,90)$ are cytotaxigenic; while products of cell damage and the supernatants from homogenized granulocytes are neutrophil cytotaxins $(12,90)$.

Vasoactive substances such as bradykinin, kallidin, histamine and serotonin give no significant neutrophil chemotactic response (88).

\section{Role of Complement in Chemotaxis and Infections}

The role of serum complement in immune lysis (57), inflammation and in resistance to bacterial infections $(5,59)$ is well known. The complement system has been strongly implicated as the biologic mediator of acute inflammation (33-36) which mobilizes immune effector cells to an inflammatory lesion $(73,74,90)$. This biologic activity is said to be mediated by activated complement components, C3a and C5a, which are believed to amplify the cellular components of the inflammatory response $(30,33,73)$.

Complement depletion affects the pathology of necrotic skin lesions. Easmon and Glynn induced skin lesions in animals with Staphylococcus aureus and showed that the ultimate dimensions of the lesions were proportional to the number of PMN neutrophils in the early infiltrate (21). Tissue enzymes, capable of activating the complement system, released by neutrophils have been implicated in tissue destruction and associated with the infectious lesions (49). 
Complement $\mathrm{C} 5 \mathrm{fr}$ is not only chemotactic but, it can trigger neutrophils to undergo a burst of oxidative metabolism $(13,51)$. During this oxidative burst, oxygen is taken up from the extracellular medium and converted to superoxide anion $\left(0_{\overline{2}}\right)$ which leads to generation of hydrogen peroxide which coupled with halides (iodide, chloride) may act as substrate for the halogenation and destruction of bacteria by the myeloperoxidase system $(13,51)$. Formylated methionyl-tripeptides (e.g. N-formyl-methionyl-leucyl-phenyalanine) induce similar oxidative bursts in responding neutrophils.

The importance of complement is highlighted by the findings that C'5-deficient mice showed deficient PMN neutrophil accumulation in response to local endotoxin; furthermore, these animals were more susceptible to microbial invasion than their C5-normal counterparts $(73,90)$.

Although phagocytosis can proceed in the absence of complement activation, complement receptors on PMN neutrophils are important for clearance and phagocytosis of opsonized particles. Lay et al reported complement factors (first 4 complement components) mediate binding of antigen-antibody complexes to neutrophil membranes during phagocytosis (48).

Immunoglobulin and components of the alternative complement pathway participated in the opsonization of $\underline{B}$. fragilis and $\underline{B}$. thetaiotaomicron by promoting phagocytosis and intracellular killing (10). The Bjornsons showed that human serum depleted of immunoglobulin, $C^{\prime} 3$, factor $B$ or $D$ did not support human PMN neutrophil phagocytosis and intracellular killing of B. fragilis and B. thetaiotaomicron (10).

Casciato et al reported that under aerobic conditions, clinical isolates of $\underline{B}$. fragilis and $\underline{B}$. thetaiotaomicron were not susceptible 
to human serum bactericidal activity (10). The Bjornsons however, demonstrated that under anaerobic conditions $\underline{B}$. fragilis and $\underline{B}$. - taiotaomicron were phagocytosed and killed intracellularly by human PMN neutrophils in the presence of normal serum but not by either neutrophils or serum alone (10).

Peterson et al found that two major opsonic systems in serum were required for normal phagocytosis for staphylococci. One was a heatlabile system dependent on $C^{\prime}$ and the other a heat-stable system mediated by immunoglobulin (64).

\section{Cellular Physiology of the Chemotactic Response}

Lonships between Chemotaxis, Enzyme release and Phagocytosis.

Chemotaxis, phagocytosis and lysosomal enzyme release are all examples of movement. In chemotaxis, there is movement of the whole cell $(7-9,46)$; in phagocytosis, movement of the cell membrane and associated structures; and in lysosomal enzyme release the granules move from the interior of the cell to the plasma membrane $(9,92)$. Similar recognition mechanisms are thought to be responsible for both chemotaxis and phagocytosis $(9,96)$. Chemotaxis, phagocytosis and enzyme release require glycolysis for metabolic energy $(8,25,96)$. Studies by Kreutzer et al and Becker et al demonstrated requirements for magnesium and calcium ions for optimal chemotaxis $(8,22,70)$.

In the absence of phagocytosis, enzyme release can occur by a process of "reverse endocytosis" $(33,34,80)$ or exocytosis. This was demonstrated by experiments employing PMN neutrophils exposed to non-phagocytosable stimuli such as: large aggregates of dead or living plaque bacteria (80), immune complexes attached to solid surfaces, surfaces too large to be 
Dhagocytosed $(33,35)$, or sepharose beads coated with $C^{\prime} 3 \mathrm{~b}$ and immunoglobulin (80). Electron microscopic studies revealed that exocytosis was apparently similar to the process following phagocytosis during which granular contents are discharged into the phagocytic vacuoles $(35,85)$. The only difference is that in exocytosis granules are discharged directly to the outside of the cell, since the whole surface could not be engulfed by the PMN neutrophil.

The respiratory burst and enhancement of hexose monophosphate shunt observed during phagocytosis is observed in cells stimulated by chemotactic factors $(7,35,85,95)$. Ward and others showed that interaction of neutrophils with chemotactic factors resulted in a respiratory burst, activation of hexose monophosphate shunt and production of lactate $(35,85)$. These results were interpreted to mean that similar or parallel metabolic pathways are required for chemotaxis and phagocytosis. Becker et al demonstrated that the ability of a peptide (C5a or low molecular weight peptide isolated from E. coli culture filtrate) to induce PMN neutrophil migration correlated directly with its ability to induce lysosomal enzyme release from cytochalasin B-treated cells (70).

Ward and Becker reported that the same enzyme, esterase 1, is activated both during chemotaxis and phagocytosis. Furthermore, in the absence of this enzyme, neither of these functions (chemotaxis and Magocytosis) can take place $(7,87)$. Bacterial factors, for unknown reasons, appear to activate a smaller proportion of the proesterase 1 (inert form of esterase 1) of neutrophils than do complement derived chemotactic factors (7). 
Ward and Becker found that after responding to a complement derived chemotactic stimulus (e.g. C $\overline{567}$, C5fr, C3fr), PMN neutrophils became "deactivated" and were not able to respond chemotactically a second time, either to the same stimulus or any other chemotactic stimulus including bacterial factors $(7,86)$. In contrast, they reported that response of rabbit PMN neutrophils to bacterial factors or incubation of the PMN meutrophils with the bacterial factors did not induce deactivation to the bacterial factor nor to any of the complement derived factors (7). Keller and Sorkin showed that although the phagocytosing neutrophil becomes unresponsive, it releases factors which attract other cells to the site of action (96).

\section{1 aments and Microtubules in the Chemotactic Response.}

The current hypothesis to explain the chemotactic response is that the microtubule system provides the net vector (polarized pseudopod formation) while the microfilament system, which requires local increases in cytoplasmic membrane calcium, provides the mechanical work for the motion of the neutrophil (26).

The exact role of microtubules is unclear; however, evidence points to the view that they direct lysosomal granules toward stimulated external membrane with which they interact (92).

Microtubules may act as a cytoskeleton, maintaining the shape of the cell and in so doing aid movement of some distant granules to the vacuoles (92). The microfilaments (actinomysinoid material), which are contractile elements of the cell, are involved in secretion (92). Microfilaments also may move granules around in the cytoplasm and normally prevent access 
of granules to the cell membrane; but by contracting, they allow freer access of granules to the cell membrane.

Cytochalasin B, a fungal metabolite, paralyzes the microfilament system and reversibly inhibits the chemotactic migration of human and rabbit PMN neutrophils $(36,96,100,101)$. There is speculative evidence that cytochalasin B, by disrupting microfilaments, allows greater movement of granules within the cytoplasm and thus enhances exocytosis of granules from PMN neutrophils (92).

One role of microtubules, another contractile system in PMN neutrophils, has been suggested by the findings that colchicine and vinblastin (drugs which cause disruption of microtubules in human and rabbit neutrophils), inhibit neutrophil motility and lysosomal enzyme release at similar dose level $(25,92,96)$. Therefore, it appears that secretion of lysosomal enzymes and chemotaxis depend upon the integrity of the cells' contractile elements

\section{Chemotaxis and Inflammation - Role in Host Defense}

\section{otaxis and Chemokinesis.}

In leukocyte chemotaxis, cells move unidirectionally toward the point of the highest concentration of the attractant, where they accumulate and movement against this gradient is inhibited. This is called "positive chemotaxis" $(25,46,84,96)$. Leukocytes may also migrate away from the source of a chemical gradient. This repulsion is called "negative chemotaxis" (96).

Chemokinesis (random walk) has been defined as "a reaction by which the speed or frequency of locomotion and/or the frequency and 
magnitude of turns of the cells is determined by the substances in the environment" $(25,95)$. Substances that only increase the rate of locomotion without influencing directional migration of cells, may not necessarily cause the cells to accumulate; because once the cells reach the source of such substances there is no force to prevent them from moving away (96). Keller and Sorkin suggested that random motility and chemotaxis involve different cellular processes (46). They further indicated that rabbit neutrophil chemotactic activity could be diminished without affecting random motion.

\section{Tof PMN Neutrophils in Host Defense}

Neutrophils, the classical cells of the inflammatory response, are considered part of the host's first line of defense (81). The role of PMN neutrophils in host defense reactions is related to their ability to engulf and destroy a wide variety of microorganisms $(2,19)$.

Cohn and Hirsch reported the presence of destructive products in PMN neutrophil lysosomes and that these products are released during phagocytosis (19). The initial bactericidal event which occurs in the cytoplasm of the neutrophil may be mediated by a number of antimicrobial agents [e.g. phagocytin (a 1ysosomal cationic protein), lysozyme (94), and lactic acid present in the neutrophil in high concentrations and with potent activities] $(19,49,76)$. In addition, neutrophils contain a variety of hydrolytic enzymes which may play a synergistic role in the digestion of engulfed particles; even though these enzymes are not directly responsible for bacterial inactivation (19). 
Ronston suggested that the phagocytic $\mathrm{N}$-acetyl- $\beta$-glucosaminidase, a hydrolytic enzyme of rabbit and human neutrophil lysosomes, may act synergistically with several intracellular enzymes to degrade Group A streptococcal cell wall within the PMN neutrophil (3).

Electron microscopic studies by Taichman et al indicated that degranulation and discharge of PMN neutrophil lysosomal enzymes were associated with phagocytosis of gram negative and gram positive bacteria, and with exocytosis of lysosomes from cells contacting large masses of aggregated plaque bacteria (80).

\section{somal Granules of Neutrophils.}

Two major granule types have been reported for PMN neutrophils:

(i) a peroxidase positive granule (called "azurophil" or primary granule)

(ii) a peroxidase negative granule (called "specific" or secondary granule) $(33,36,76,94,95,99)$.

In rabbit neutrophils, the azurophilic granules contain acid hydrolases, whereas the specific granules contain alkaline phosphatase, lysozyme and lactoferin but are free of acid phosphatase $(4,33,76)$.

Myeloperoxidase has been used as a marker for azurophilic lysosomal granules and lysozyme is commonly used as a marker for specific granules even though lysozyme is not solely restricted to the specific granules (94).

Neutrophils, during chemotaxis or stimulated by either phagocytosis or adherence to non-phagocytosable surfaces, release $\beta$-glucuronidase, B-galactosidase, acid phosphatase and myeloperoxidase (which are known to reside mainly in the primary "lysosomal" or azurophilic granule) (33). 
The presence of $\mathrm{N}$-acetyl- $\mathrm{B}-\mathrm{glucosaminidase}$ activity in mammalian tissues has been reported by several investigators $(3,61,65,98)$. Ayoub and McCarthy demonstrated the occurence of $\mathrm{N}$-acetyl- $\beta$-glucosaminidase activity in mammalian neutrophils (3). They showed that $\mathrm{N}$-acetylB-glucosaminidase from phagocytic cells differed greatly from that obtained from soil bacilli. Sellinger, Hay and others studied the intracellular distribution of $\mathrm{N}$-acetyl- $\beta$-glucosaminidase, an acid hydrolase, in various tissues (3). They showed this enzyme to be lysosome-associated.

\section{logic Release from Polymorphonuclear Neutrophils.}

Although several reports suggest that extracellular release of granular enzymes is a useful function of the inflammatory cell defending the body; it has also been suggested that in protecting the host from a generalized infection, the neutrophil may cause tissue damage at the site of phagocytosis $(80,81,87)$.

In immune vasculitis, tissue injury results from the inflammatory response itself rather than from the stimulus that evoked the response $(87,99)$. Neutrophils contain injurious constituents within their granules (e.g. Lysozyme). Neutrophil accumulation at the site of immune complex deposition is also accompanied by the phagocytosis of the complexes $(33,35)$. During this process, some of the neutrophil granular contents may escape to the outside of the cell and cause tissue damage. Henson demonstrated that during exocytosis, granules are extruded directly to the outside environment of the cell (35). Tissue damage occurs in such cases. Some examples of this are acute necrotizing, ulcerative 
gingivitis and juvenile periodontal infections, where evidence showing that while phagocytosing large aggregates of plaque bacteria (by exocytosis), PMN neutrophils cause tissue destruction $(18,32,80,81)$.

The release of bactericidal and bacteriostatic agents from neutrophils affects not only neutralization and killing of microorganisms, but also amplifies and localizes the inflammatory response $(27,99)$.

Goetz and Austen have described a "neutrophil-immobilizing factor" released from PMN neutrophils following exposure to bacterial endotoxin (27). This immobilizing factor inhibited the response of human neutrophils to diverse chemotactic stimuli without affecting cell viability.

\section{Drugs Which Affect Chemotaxis}

Henson and others have reported that cytochalasin B prevents phagocytic uptake of particles by PMN neutrophils, by disruption of microfilaments $(35,101)$. They further stated that the inhibitory effect of cytochalasin B on glucose oxidation was due to the fact that cytochalasin B acts upon the cell membrane and thus inhibits transport of glucose into the cell $(35,92,101)$.

Showell, Kruetzer, Ward and others have demonstrated that interaction of chemotactic factors with cytochalasin B-treated cells (PMN neutrophils) enhances release of lysosomal enzymes $(7,36,70,89)$. Cytochalasin $B$ reportedly acts by enhancing exocytosis (92).

Zurier et al reported that prior treatment of PMN neutrophils with cyclic nucleotides, prostaglandin $E_{1}$ or with compounds that interfere with microtubule function (e.g. Vinblastin and Colchicine), blocked enzyme release (101). Henson et al showed that lysosomal enzyme release 
was inhibited by diisopropyl fluorophosphate and agents that increase intracellular concentration of CAMP (35).

Ward confirmed the inhibitory effects of steroids, hydrocortisone and methyl prednisolone (anti-inflammatory drugs), on chemotaxis of glycogen-induced rabbit peritoneal neutrophils (83). He showed that chloroquine, hydrocortisone and corticosteroids have a direct effect on PMN neutrophils rendering them incapable of responding to a chemotactic stimulus $(25,83)$.

Aspirin, a non-steroidal anti-inflammatory drug $(85,92)$ apparently has no suppressive effect on chemotaxis. However, aspirin appears to suppress inflammation by blocking prostaglandin synthesis $(85,92)$.

\section{Disorders of Neutrophil Chemotaxis}

The discovery of syndromes involving defective neutrophil chemotaxis leading to increased susceptibility to bacterial infections adds strength to the arguments in favor of the essential role of chemotaxis in infections. One example of such syndromes is chronic granulomatous disease of childhood. It is characterized by recurrent, severe bacterial infections, dermatitis and chronic suppurative and granulomatous lymphadenitis $(51,57,85,96)$.

In Chediak-Higashi syndrome, a familial leukotactic defect, children show defective neutrophil migration $(18,25,60,85)$. This syndrome is characterized by defective bactericidal activity in the presence of normal ability to ingest bacteria, partial occulomatous albinism, and a history of recurrent severe pyogenic infections. The presence of $a b-$ normal giant cytoplasmic lysosomal granules is inherent of the defective neutrophils. 
In 1971, Miller et al reported two children with depressed neutrophil mobility and recurrent infection. This syndrome was termed the "Leukocyte-Syndrome" (57). This syndrome is characterized by gingivitis, stomatitis and recurrent upper respiratory tract infections. The patients' neutrophils demonstrate normal capacity for phagocytosis and bacterial killing with abnormal membrane receptors for chemotactic factors.

In diabetes melitus, neutrophils show a partially-defective chemotactic response. This defect was corrected in vitro by addition of insulin and potassium to the neutrophil suspension $(60,86)$.

Apart from the development of a new technique for measurement of leukocyte chemotaxis by Boyden (14); interest in chemotaxis has soared, because of the recognition of chemotactic defects in certain patients with chronic bacterial infections.

Mowat et al were the first to report evidence that severe infections may depress leukocyte function (60). They showed that neutrophils of patients with overwhelming bacterial infections, including tuberculosis infections, were less chemotactically responsive than neutrophils from heal thy individuals.

In 1969, Ward et al reported that a child who was subject to frequent gram negative bacterial infections had an inhibitor of human neutrophil chemotaxis in his serum. This inhibitor appeared to act directly on neutrophils, but did not affect the chemotactic stimulus (27).

Ingham et al reported that serum reacted with $\underline{B}$. fragilis or $\underline{B}$. laninogenicus was able to inhibit phagocytosis and killing of 
Proteus mirabilis by PMN neutrophils in vitro (38).

Defective neutrophil chemotaxis has been frequently associated with juvenile periodontitis $(18,80)$.

In 1974, Boxer et al described a male infant with repeated bacterial infections and a poor in vivo inflammatory response in affected tissues (13). Their in vitro studies demonstrated defects in PMN chemotaxis and phagocytosis but enhanced degranulation (13).

The only report concerning the effect of bacteria and their products on the migration of leukocytes was made by Martin and Chaudhuri (15). They stated that purified gram negative bacterial product (Typhoid somatic carbohydrate) and whole Salmonella typhi $\left(6 \times 10^{6} \mathrm{org} / \mathrm{ml}\right)$ but not staphylococcus or pneumococcus inhibited the migration of human PMN neutrophils suspended in plasma (15). 


\section{MATERIALS AND METHODS}

sterial Strains

Bacteria used in this study were obtained from Virginia Polytechnic Institute and State University (VPI), Blacksburg, Virginia. The three species of Bacteroides used were Bacteroides fragilis [VPI 9032, VPI 5383 (ATCC 23745), VPI 2553 (ATCC 25285)] clinical isolates, Bacteroides vulgatus [VPI 4245 (ATCC 8482)] a fecal isolate, and Bacteroides thetaiotaomicron [VPI 5482 (ATCC 29184)] a fecal isolate.

Stock cultures were maintained after growth for 24 hours at $37^{\circ} \mathrm{C}$, at room temperature under oxygen-free $\mathrm{CO}_{2}$ in pre-reduced chopped-meat broth (Appendix B).

\section{aration of Bacterial Chemotactic Factor}

The defined medium used in preparing the bacterial factor was a modification of the medium of Varel and Bryant (75). It contained per liter of distilled water: glucose, $5 \mathrm{~g} ;\left(\mathrm{NH}_{4}\right)_{2} \mathrm{SO}_{4}, 1 \mathrm{~g} ; \mathrm{KH}_{2} \mathrm{PO}_{4}, 0.9 \mathrm{~g}$; $\mathrm{NaCl}, 0.9 \mathrm{~g} ; \mathrm{CaCl}_{2} \cdot 2 \mathrm{H}_{2} \mathrm{O}, 26.5 \mathrm{mg} ; \mathrm{MgCl}_{2} \cdot 6 \mathrm{H}_{2} \mathrm{O}, 2 \mathrm{mg} ; \mathrm{MnCl}_{2} \cdot 4 \mathrm{H}_{2} \mathrm{O}, 2 \mathrm{mg}$; $\mathrm{FeSO}_{4} \cdot 7 \mathrm{H}_{2} \mathrm{O}, 4 \mathrm{mg}$; $\mathrm{CoCl}_{2} \cdot 6 \mathrm{H}_{2} \mathrm{O}$, Img; resazurin, $1 \mathrm{mg}$; and Vitamin $\mathrm{B}_{12}, 10 \mu \mathrm{g}$. The medium was adjusted to $\mathrm{pH} 6.5$ with $\mathrm{NaOH}$ and sterilized at $121^{\circ} \mathrm{C}$ for 15 minutes. To this medium, $20 \mathrm{ml}$ of sterile $25 \%$ (wt/vol) cysteine-HCl and $50 \mathrm{ml}$ of sterile $8 \%$ (wt/vol) $\mathrm{Na}_{2} \mathrm{CO}_{3}$ (each prepared in $\mathrm{O}_{2}$-free water and kept under an atmosphere of $\mathrm{CO}_{2}$ ) were added asceptically under oxygen free $\mathrm{CO}_{2}$. Under oxygen-free $\mathrm{CO}_{2}, 7 \mathrm{ml}$ aliquots of the medium were dispensed into tubes and autoclaved in a press at $121^{\circ} \mathrm{C}$ for 15 minutes. 
One half $\mathrm{ml}$ of stock culture of organisms was transferred by pipette into a $7 \mathrm{ml}$ tube of Varel and Bryant's modified defined medium under $\mathrm{O}_{2}$-free $\mathrm{CO}_{2}$ and this culture was incubated at $37^{\circ} \mathrm{C}$ for 24 hours. The culture was centrifuged at $5000 \times \mathrm{g}$ for 30 minutes. The supernatant was carefully removed with a sterile pipette and then filter sterilized by passing the culture supernatant through membrane filters, $0.45 \mu \mathrm{m}$ pore diameter (Millipore Corporation, Bedford, Massachusetts). The concentrated cell suspension left in the tube of medium was checked for contamination. The sterile culture filtrates were stored at $-20^{\circ} \mathrm{C}$ until used.

\section{tetion of Bacteroides Lipopolysaccharide (LPS)}

Lipopolysaccharide was extracted from Bacteroides fragilis VPI 9032 by the hot water-phenol extraction method of Westphal (37).

1) Two tubes containing $25 \mathrm{ml}$ of Trypticase Yeast Extract Glucose (TYG) medium containing per liter of distilled water: Trypticase, 10g; Yeast extract, $10 \mathrm{~g}$; resazurin (25mg per $100 \mathrm{ml}$ of distilled water), 4m1; salts solution, $40 \mathrm{ml}$; glucose, $10 \mathrm{~g}$; hematin ( $50 \mathrm{mg}$ hemin in $1 \mathrm{ml}$ of $1 \mathrm{~N}$ $\mathrm{NaOH}$, add $99 \mathrm{ml}$ of distilled water), $10 \mathrm{ml}$; adjusted to $\mathrm{pH} 7.0$, were each inoculated with $0.5 \mathrm{ml}$ of stock chopped-meat culture of Bacteroides under $\mathrm{O}_{2}$-free $\mathrm{CO}_{2}$ and grown overnight at $37^{\circ} \mathrm{C}$.

2) Fifty milliliters of an overnight TYG culture was added per liter of TYG which was then incubated for $24-48$ hours.

3) The bacterial cells were harvested by centrifugation at $12,000 \times \mathrm{g}$ for 10 minutes, washed $2 x$ with $0.9 \%$ normal saline and frozen $\left(-20^{\circ} \mathrm{C}\right)$.

4) Cells (25g, wet weight) harvested from 10 liters were dried in 
the following manner:

a. $150 \mathrm{ml}$ of $95 \%$ ethanol $\left(4^{\circ} \mathrm{C}\right)$ were added to the cells with stirring and the mixture was centrifuged at $12,000 \times \mathrm{g}$ for 10 minutes at $4^{\circ} \mathrm{C}$.

b. $150 \mathrm{ml}$ of acetone $\left(4^{\circ} \mathrm{C}\right)$ was added to pellet. The pellet was resuspended then centrifuged at $12,000 \times \mathrm{g}$ for 10 minutes at $4^{\circ} \mathrm{C}$.

c. The resulting pellet was resuspended in $150 \mathrm{ml}$ of diethyl ether $\left(4^{\circ} \mathrm{C}\right)$ and centrifuged at $10,000 \times \mathrm{g}$ for 10 minutes at $4^{\circ} \mathrm{C}$.

5) The dried cells (approximately $5 \mathrm{~g}$ ) were pulverized and dried in a vacuum dessicator to a constant weight.

6) $5 \mathrm{~g}$ of dried bacteria were suspended in $70 \mathrm{ml}$ of distilled water in a $68^{\circ} \mathrm{C}$ water bath.

7) $70 \mathrm{ml}$ of $90 \%$ ( $w t / v 0 l$ ) phenol (preheated to $68^{\circ} \mathrm{C}$ ) were added with vigorous stirring. This was incubated for 30 minutes at $68^{\circ} \mathrm{C}$ with intermittent agitation, then cooled to about $10^{\circ} \mathrm{C}$ in an ice bath.

8) The mixture was centrifuged at $8,000 \times g$ for 45 minutes, and the upper layer (which contains lipopolysaccharide, nuclei acids and polysaccharides) was aspirated off.

9) To the phenol layer and insoluble residue, $70 \mathrm{ml}$ of water $\left(68^{\circ} \mathrm{C}\right)$ were added, stirred and heated to $68^{\circ} \mathrm{C}$ for 30 minutes.

10) The mixture was cooled to $10^{\circ} \mathrm{C}$ in an ice bath and Step 8 was repeated.

11) The combined aqueous layers were dialyzed against distilled water for three days with numerous changes of water to remove the phenol. 
12) The volume was reduced to about $14 \mathrm{ml}$ by reduced pressure evaporation at $40^{\circ} \mathrm{C}$.

13) This was centrifuged for 15 minutes at $3,000 \times \mathrm{g}$ at $4^{\circ} \mathrm{C}$ and the pellet was discarded.

14) The supernatant was lyophilized and this was designated crude lipopolysaccharide (LPS).

15) The crude lipopolysaccharide was resuspended in distilled water ( $3 \mathrm{~g}$ per $100 \mathrm{ml}$ ) and centrifuged $105,000 \times \mathrm{g}$ for four hours. The pellet was resuspended in distilled water and centrifuged $(105,000 \times \mathrm{g}$ for four hours) twice more.

16) The pellet was resuspended in distilled water and centrifuged at $3,000 \times \mathrm{g}$ for 10 minutes and the pellet was discarded.

17) The supernatant was lyophilized.

\section{ation of Crude Bacteroides outer membrane $(40,43)$.}

Under oxygen-free $\mathrm{CO}_{2}$, two tubes containing 25ml Trypticase Yeast Glucose (TYG) medium, were innoculated with $0.5 \mathrm{ml}$ of stock chopped-meat culture of Bacteroides and grown overnight at $37^{\circ} \mathrm{C}$. Fifty milliliters of an overnight TYG culture of Bacteroides was added per liter of TYG. This was allowed to grow for $24-48$ hours at $37^{\circ} \mathrm{C}$. All cultures were checked for contamination. Organisms were pelleted by centrifugation at $12,100 \times \mathrm{g}$ for 20 minutes and then washed $2 \times$ in $0.05 \mathrm{M}$ phosphate buffer. Pelleted organisms were suspended in a buffer containing: $0.05 \mathrm{M}$ sodium phosphate, 0.15M NaCl and 0.01M EDTA, and adjusted to $\mathrm{pH} 7.4$ at $24^{\circ} \mathrm{C}$ (the final volume was about $1 / 50$ of original culture). The cell suspension was incubated at $60^{\circ} \mathrm{C}$ for 30 minutes and then passed through a $25-$ gauge hypodermic needle, after which the suspension was mixed for 10 
seconds in a Waring Blender. Organisms were pelleted from this suspension by centrifugation at $12,000 \times \mathrm{g}$ for 20 minutes at $4^{\circ} \mathrm{C}$. The supernatant was centrifuged at $80,000 \times \mathrm{g}$ for two hours at $4^{\circ} \mathrm{C}$. The pellet (crude outer membrane) was lyophilized (freeze dried).

\section{Peritoneal Exudate Cells}

The procedure used for harvesting rabbit peritoneal polymorphonuclear neutrophils (PMN) is similar to that employed by other investigators $(22,70)$. Adult New Zealand White Rabbits (Glouchester Rabbitry, Chepachet, Rhode Island) were injected intraperitoneally with $100 \mathrm{ml}$ of sterile $0.1 \%$ (wt/vol) glycogen in isotonic saline. Four to seven hours later, $100 \mathrm{ml}$ of sterile heparinized-saline (5 units heparin/ml) were introduced into the peritoneal cavity. The peritoneal exudate was withdrawn via 16 gauge canula into plastic containers by gravity drainage. These rabbits had been repeatedly primed with $0.1 \%$ glycogen in saline to produce large numbers of exudate cells prior to their use in these experiments. Rabbits were not injected with glycogen-saline more than once in every three weeks. Any contaminating erythrocytes in peritoneal exudates were lysed with $\mathrm{NH}_{4} \mathrm{Cl}, \mathrm{pH} 7.3$, and exudates contaminated with large amounts of erythrocytes were discarded. The rabbit peritoneal exudates were centrifuged in plastic tubes at $1,000 \times \mathrm{g}$ for five minutes at $4^{\circ} \mathrm{C}$. Pelleted peritoneal PMN neutrophils were washed twice with at least $30 \mathrm{ml}$ of sterile normal saline. A concentrated cell suspension of the peritoneal PMN neutrophils was made in saline. Wright stained smears and wet mount differential counts revealed that this suspension contained 98\% PMN neutrophils. Appropriate dilutions of the concentrated cell suspension were made in Hank's balanced salts solution (HBSS) 
containing $0.05 \%$ (wt/vol) Bovine serum albumin. For chemotaxis assays $2.5 \times 10^{6} \mathrm{cel} 1 \mathrm{~s} / \mathrm{m} 1$ were employed whereas $1 \times 10^{7}$ cel1s $/ \mathrm{m} 1$ were routinely used for enzyme release assays.

\section{Chemotaxis Chambers}

Modified Boyden Chambers with steel housing were used for Chemotaxis experiments. The chambers were assembled with a $25 \mathrm{~mm}$ coverslip; a soft silicone rubber gasket ( $25 \mathrm{~mm}$ outside diameter and $19 \mathrm{~mm}$ inside diameter); pre-tested membrane filter, $25 \mathrm{~mm}$ diameter, $0.8 \mu \mathrm{m}$ porosity, and $150 \mu \mathrm{m}$ thick; another gasket; a $25 \mathrm{~mm}$ coverslip again, and then closed with a screw top. The chamber was thus separated into an upper and a lower compartment with a membrane filter separating the two compartments. The lower chamber was loaded by injecting the material (about $0.8 \mathrm{ml}$ ) tested for chemotactic activity or HBSS with a tuberculin syringe (26 gauge needle) through one of the ports at the side of the Boyden chamber. While filling the compartment, a needle was placed in the opposite port to allow air to escape. The material in the lower compartment was allowed to diffuse through filter to the upper compartment of the filter to produce a concentration gradient. A $1 \mathrm{~m} 1$ aliquot of rabbit peritoneal PMN neutrophils was placed in the upper compartment of each Boyden chamber. When bacterial products (culture filtrates, outer membrane and LPS) were tested for ability to induce random locomotion (chemokinesis)/or directed migratory response (chemotaxis), they were added to both the upper and lower compartments in varying concentrations, in keeping with the method described by Zigmond and Hirsch (100). All filters used in this study were from one batch, tested and proven membrane (Pathology Department, 
University of Connecticut, Health Center, Farmington, Connecticut). This incubation period was chosen because upon testing the membrane filters, the greatest difference between the number of cells moving into the filter with no chemotactic stimulus in the lower compartment (background) and the maximum number of cells moving into the filter in response to a chemotactic attraction from the lower compartment was found after one hour incubation. Duplicate chambers were incubated at $37^{\circ} \mathrm{C}$ for 60 minutes.

\section{prphonuclear Neutrophil Chemotaxis Measurement}

Modified Boyden Chambers were disassembled after the appropriate incubation period. A procedure similar to that of Boyden (14) was used to process the membrane filters. A brass cassette (Schleischer and Shuell) which permits simultaneous staining of 25 filters was used to facilitate this process. Micropore filters removed from dismantled chambers were quickly immersed in $100 \%$ isopropyl alcohol and fixed for 3 minutes. The cells on the filters were stained as follows:

a. Erhlich's hematoxylin 6 - 10 minutes.

b. Rinsed in distilled water 30 seconds.

c. Blueing agent $\left(20 \mathrm{~g} \mathrm{MSO}_{4}, 2 \mathrm{~g} \mathrm{NaHCO}_{3} / 1\right.$ liter of distilled water) 6 - 10 minutes.

d. Rinsed in distilled water 30 seconds.

e. Dehydrated in $70 \%$ isopropyl alcohol, two minutes.

f. $95 \%$ isopropyl alcohol, two minutes.

g. $100 \%$ isopropyl alcohol, two minutes.

h. $100 \%$ isopropyl alcohol again, two minutes.

i. Filters were cleared in xylene. 
The filters were mounted on microscope slides with permount (Fisher Scientific Company, Pittsburg, Pennsylvania). The high power objective (40x) and 10x ocular of a microscope were used to count the cells; while the micrometer of the fine adjustment was used to measure the distance from the top of the membrane filter to the farthest plane of focus still containing two cells. This distance was measured for at least three random (ocular grid) fields. Duplicate chambers were assayed and the data represent the mean measurements of the two membrane filters examined. Increases in distance travelled into the membrane filter of $10 \mu \mathrm{m}$ above negative control by PMN neutrophils migrating toward an attractant are statistically significant (25).

The Chemotactic Index (CI, the average distance that cells migrate in one hour at $37^{\circ} \mathrm{C}$ ) was calculated in the following manner:

Cells in focus were counted at each $10 \mu \mathrm{m}$ from original monolayer to the distant plane of the membrane filter. The number of cells counted per level was multiplied by the distance (in $\mu \mathrm{m}$ ) of that level from the starting monolayer. The sum of the products obtained was divided by the total number of migrated cells.

\section{Detfe Factor Derived From Human Complement 5 th Component (C5fr)}

The purified C5ff was supplied by Donald L. Kreutzer of the University of Connecticut Health Center, Farmington, Connecticut. The chemotactically active $\mathrm{C} 5 \mathrm{fr}$ were stored at $-20^{\circ} \mathrm{C}$ in $0.5 \mathrm{ml}$ aliquots. The solution was thawed before use and $1.5 \mathrm{ml}$ of $0.5 \mathrm{M}$ dibasic sodium phosphate pH 7.2 - 7.4 was added. Chemotactic activity of the C5fr. 
was normalized by determining the quantity of $\mathrm{C} 5 \mathrm{fr}$ that produced $50 \%$ of the maximal chemotactic response in Boyden Chambers (22). Three times this quantity of $\mathrm{C} 5 \mathrm{fr}$ was used to assure consistent maximum chemotaxis and enzyme release from one cell preparation of polymorphonuclear neutrophils to another.

\section{and Lysosomal Enzyme Release}

The ability of Bacteroides products, C5fr, Varel and Bryant's defined medium, and HBSS buffer to trigger the release of $\mathrm{N}$-acetyl- $\beta$ D-glucosaminidase from rabbit peritoneal PMN neutrophils was assayed by an adaptation of the Method of Wollen et al (3). p-nitrophenyl $N$-acety $1-\beta-D-g l$ cosaminide was the substrate for determining amount of enzyme released.

Washed rabbit peritoneal exudate cells were suspended at a final concentration of $1 \times 10^{7} \mathrm{cell} \mathrm{s} / \mathrm{ml}$ in Hanks balanced salts solution containing $0.05 \%$ (wt/vol) Bovine serum albumin. One $\mu \mathrm{g}$ of a stock solution (4mg per $\mathrm{ml}$, in dimethyl sulfoxide) of cytochalasin B (Sigma Chemical Company, Milwaukee, Wisconsin) was added per $\mathrm{ml}$ of cell suspension. Dimethyl sulfoxide has no effect on the enzyme release response (70). Cells, samples tested, and tubes used in these experiments were all equilibrated at $4^{\circ} \mathrm{C}$, except where otherwise stated. One-half milliliter

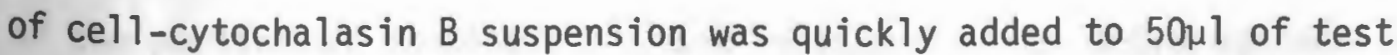
material [known chemotactic factor (C5fr), buffer (HBSS), or bacterial Product] in plastic tubes. The mixtures were incubated for five minutes in a $37^{\circ} \mathrm{C}$ gyrotory water bath shaker. Release is completed in one minute or less under these conditions (70). Tubes were centrifuged at $2,000 \times \mathrm{g}$ 
for five minutes at $4^{\circ} \mathrm{C}$. The cell supernatants were transferred to clean tubes for assay of $\mathrm{N}$-acetyl-B-D-glucosaminidase activity. Aliquots of these supernatants were kept (at $4^{\circ} \mathrm{C}$ ) for measurement for lactate thydrogenase. Cell pellets were discarded.

\section{tyl-B-D-glucosaminidase Assay}

Equal volumes $(0.5 \mathrm{ml})$ of freshly prepared $\mathrm{p}$-nitrophenyl $\mathrm{N}$-acetyl$B-D-g l u c o s a m i n i d e ~(1.4 m g$ per $\mathrm{ml}$ in $0.05 \mathrm{M}$ sodium citrate,buffer, $\mathrm{pH} 4.5$ ) and cell supernatant were mixed by vortex. Mixtures were incubated at $37^{\circ} \mathrm{C}$ in a gyrotory shaking water bath for one hour. Following incubation $0.5 \mathrm{ml}$ of glycine buffer $(0.4 \mathrm{M}, \mathrm{pH} 10.5)$, was added to the mixture to stop the reaction. p-Nitrophenol (a yellowish colored compound) was liberated from the substrate in the presence of $N$-acetyl-B-D-glucosaminidase. Absorbance was read at $410 \mathrm{~nm}$ in a Gilford spectrophotometer. Positive ( $\mathrm{C} 5 \mathrm{fr}$ ) and negative (HBSS) controls were included with each assay. Additional control mixtures containing only bacterial products were employed to demonstrate that these bacterial products had no glucosaminidase activity. All tests were performed in triplicate.

\section{ate Dehydrogenase (LDH) Assay}

Bacteroides products were assayed for the ability to trigger lysis of the peritoneal exudate cells and release lactate dehydrogenase (a cytoplasmic enzyme) from rabbit peritoneal neutrophils according to the method in Biochemical Information (11). This is a standard assay which measures the oxidation of reduced nicotinamide adenine dinucleotide (NADH) during the reduction of pyruvate to lactate. 

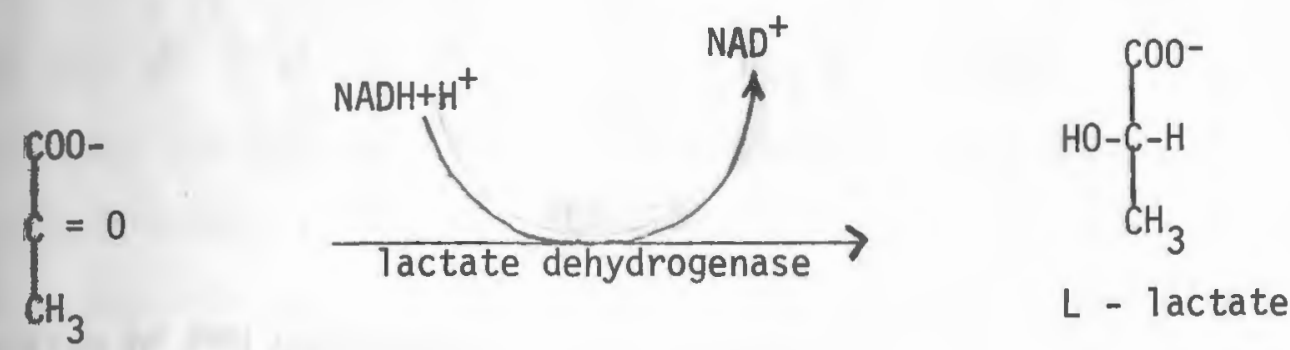

Pyruvate

The reaction mixture contained: $2.83 \mathrm{ml}$ of $0.1 \mathrm{M}$ phosphate buffer, pH 7.0 (530mg $\mathrm{KH}_{2} \mathrm{PO}_{4}+1.39 \mathrm{~g} \mathrm{~K}_{2} \mathrm{HPO}_{4} \cdot 3 \mathrm{H}_{2} \mathrm{O} / 100 \mathrm{ml}$, cooled at $4{ }^{\circ} \mathrm{C}$ in an ice bath); $0.1 \mathrm{ml}$ of $23 \mathrm{mM}$ sodium pyruvate solution (25mg sodium pyruvate/ $10 \mathrm{ml}$, cooled to $4^{\circ} \mathrm{C}$ in an ice bath); and $0.05 \mathrm{ml}$ of $12 \mathrm{mM} \mathrm{NADH}$ solution (100mg NADH, Na2 - salt/10ml, cooled to $4{ }^{\circ} \mathrm{C}$ in an ice bath).

The enzyme reaction was initiated by addition of $0.02 \mathrm{ml}$ of cellfree supernatant. Absorbance at $340 \mathrm{~nm}\left(A_{340}\right)$ was read after one, two, three, four and five minutes. Change in $A_{340}$ per minute $\left(\Delta A_{340}\right)$ was used to report the level of lactate dehydrogenase activity. All assays were performed in triplicate.

\section{Reagents}

Cytochalasin B, p-nitrophenyl-B-D-glucosaminide, and guinea pig complement were obtained from Sigma Chemical Company, Saint Louis, Missouri. All other reagents used in this study were of analytical grade. 
RESULTS

\section{tion of PMN Locomotion}

The crude outer membrane (OM) of Bacteroides fragilis (VPI 5383) was assayed at various concentrations to determine possible chemotactic activity for PMN neutrophils. The response of rabbit peritoneal PMN neutrophils was positive for locomotion, and the level of response was dependent upon the amount of OM added (Figure 1). Cell-free culture filtrates (CF) of $\underline{B}$. fragilis (VPI 9032) and $\underline{B}$. thetaiotaomicron (VPI 5482) showed a similar positive chemotactic response to increasing doses

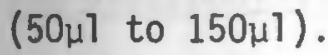

Bacteroides were cultured in a defined medium formulated by Varel and Bryant (75). Table 1 gives the results for the positive and negative controls included in the chemotaxis experiments employing Boyden chambers. The buffer, Hank's balanced salt solution (HBSS), gave no locomotion of PMN neutrophils; nor did several concentrations of fresh sterile Varel and Bryant defined minimal medium. The positive control, activated $\mathrm{C5}$ fragment of serum complement, always elicited positive chemotaxis; demonstrating that the rabbit PMN neutrophils used in the assay were indeed responsive to chemotactic stimuli.

\section{motaxis versus Chemokinesis}

Figure 2 demonstrates the response of rabbit PMN neutrophils to B. vulgatus (VPI 4245) OM was indeed Chemotactic (locomotion directed toward a concentration gradient). When concentrations of 50 to $150 \mathrm{\mu g}$ 
of OM were added to the lower compartment, movement toward the lower compartment increased. When 50ug of OM were added to the upper compartment movement of PMN neutrophils was only observed when the concentration of $\mathrm{OM}$ in the lower compartment was above 50 $\mathrm{\mu g}$. When the $\mathrm{OM}$ concentration in the upper compartment was increased to $100 \mathrm{\mu g}$, downward movement of the PMN neutrophils was only observed when the OM concentration in the lower compartment exceeded 100ug. Finally when the upper compartment contained $150 \mathrm{ng}$ of $\mathrm{OM}$, there was no movement of the PMN medtrophils toward the lower compartment.

ction of Bacteroides Cellular Components or Products with Rabbit

Neutrophils.

Lipopolysaccharide (LPS), CF and OM of $\underline{B}$. fragilis showed some chemotaxis of rabbit PMN neutrophils (Table 2). The activity of the LPS of $\underline{B}$. fragilis (VPI 9032) was increased significantly by pre-incubation with guinea pig complement at $37^{\circ} \mathrm{C}$ for 30 minutes; while the $\mathrm{CF}$ and $\mathrm{OM}$ gave a very negative reaction with PMN neutrophils after preincubation with guinea pig complement (Table 2). There appeared to be an inhibitor of chemotaxis produced when CF or OM was pre-incubated with guinea pig complement.

When the purified C5 fragment of complement was reacted with CF or OM, the chemotactic response of PMN neutrophils was significantly reduced; however, not back down to the negative control level (Table 3). When the amount of OM (VPI 5383) was increased to $62.5 \mu \mathrm{g} / \mathrm{ml}$, the chemotactic activity of the C5 fragment was completely abolished. 


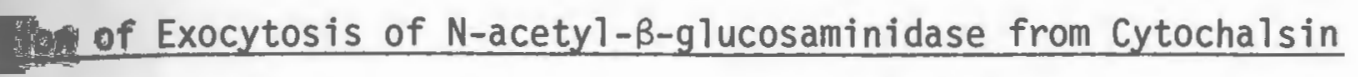
Rabbit PMN Neutrophils by Bacteroides Cellular Components or

Products.

Culture filtrate of $\underline{B}$. fragilis (VPI 2553 and VPI 5383) and $\underline{B}$. vulgatus (VPI 4245) caused a slight exocytosis of N-acetyl-B-glucosaminidase (Table 4). The LPS of $\underline{B}$. fragilis (VPI 9032) and OM (VPI 2553, VPI 5383 and VPI 9032) did not cause any significant exocytosis (Table 4). However, when the CF, LPS or OM were pre-incubated with guinea pig complement at $37^{\circ} \mathrm{C}$ for 30 minutes, they released as much or more $\mathrm{N}$-acetylB-glucosaminidase activity from the cytochalasin B-treated neutrophils as the $\mathrm{C} 5$ fragment (Table 5). No significant difference was observed when the guinea pig complement was added to the reaction mixture and assayed without pre-incubation. When the guinea pig complement was heatinactivated $\left(55^{\circ} \mathrm{C}\right.$ for 30 minutes) prior to mixing Bacteroides cellular components or products, the exocytosis response was reduced by about one-half. When these cellular components or products of Bacteroides were incubated in the reaction mixture, in the absence of PMN neutrophils, no color developed; indicating that the bacteria had no N-acetyl-B-glucosaminidase activity. Furthermore, no detectable level of lactate dehydrogenase could be measured in the positive exocytosis reaction mixtures; indicating that PMN neutrophil lysis was not required for the release of N-acety1- $\beta$-glucosaminidase, because lactate dehydrogenase is only found free in the cytoplasm of PMl neutrophils. 
Figure 1. Dose response of rabbit PMN neutrophils

to Bacteroides fragilis (VPI 5383) outer membrane

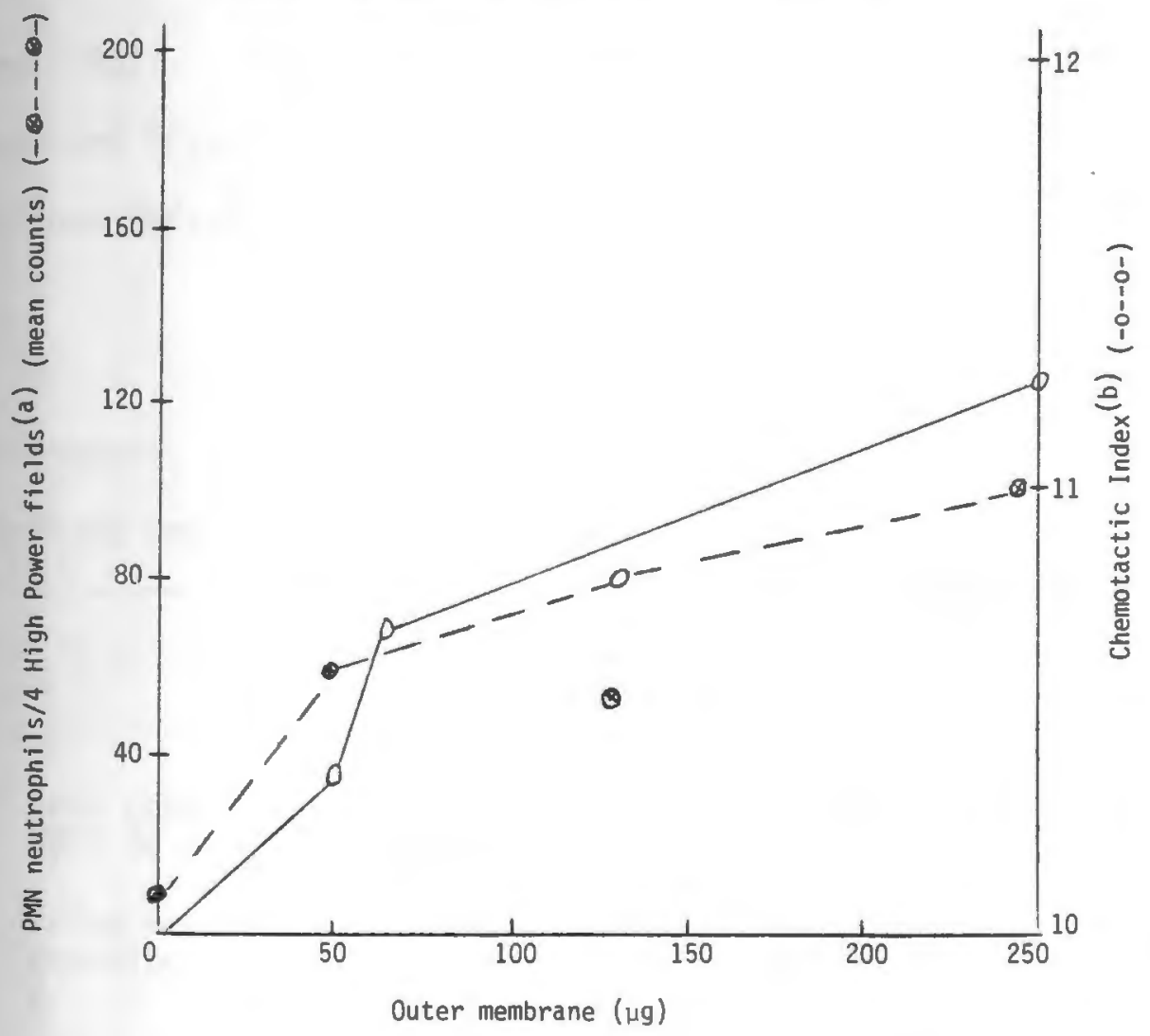

a) Each point on graph represents the mean cell count in four fields for duplicate Boyden chambers.

b) The Chemotactic Index is the average distance (in $\mu \mathrm{m}$ ) the PMN neutrophils have penetrated into the membrane filter in one hour at $370^{\circ} \mathrm{C}$. 
Table 1. Chemotactic Response of Rabbit PMN

Neutrophils to the Defined Medium of Varel and Bryant

\section{Additions to}

Lower Compartment

$$
\text { Dept }=\underline{10 \mu \mathrm{m}} \quad \underline{20 \mu \mathrm{m}}
$$

PMN neutrophi1s/2HPF (mean $\pm s d$ )

(d)

Chemotactic Activity

$20.5 \pm 4.2 \quad 0$

$\underline{30 \mu m}$

0

$\underline{40 \mu \mathrm{m}}$

None (HBSS)

Varel and Bryant

Defined Medium: 5

$100 \mu 111 \pm 2.1 \quad 0$

$150 \mu 115.5 \pm 0.350$

0

0

0

0

0

0

0

0

10.0 Chemotactic Index

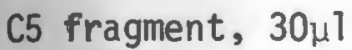

(Positive Control)
a) Each concentration of Varel and Bryant defined medium was added to HBSS $(0.8 \pm 0.2 \mathrm{ml})$ in lower compartment

b) Value not included in calculating Chemotactic Index (average distance traveled per neutrophil), because leading front cells were less than 2.

c) The Chemotactic Index is the average distance (in $\mu \mathrm{m}$ ) the PMN neutrophils have penetrated into the membrane filter in one hour at $37^{\circ} \mathrm{C}$.

d) The values represent the mean cell count ( $\pm s d$ ) in two high power fields for duplicate chambers. 
Figure 2. Locomotion of Rabbit PMN Neutrophils in Established Gradients of Bacteroides vulgatus VPI 4245 outer membrane

Chemokinesis
PMN Neutrophils/4 H.P.F. (mean \pm SEM) $(a)$

Concentration $(\mu \mathrm{g} / \mathrm{m} 1)$

of OM 4245

Above Filter

0

50

100

150

B.

Concentration $(\mu \mathrm{g} / \mathrm{m} 1)$ of OM 4245

Above Filter

0

50

100

150
Concentration of OM 4245

Below Filter

$\underline{50} \quad \underline{100} \quad \underline{150}$
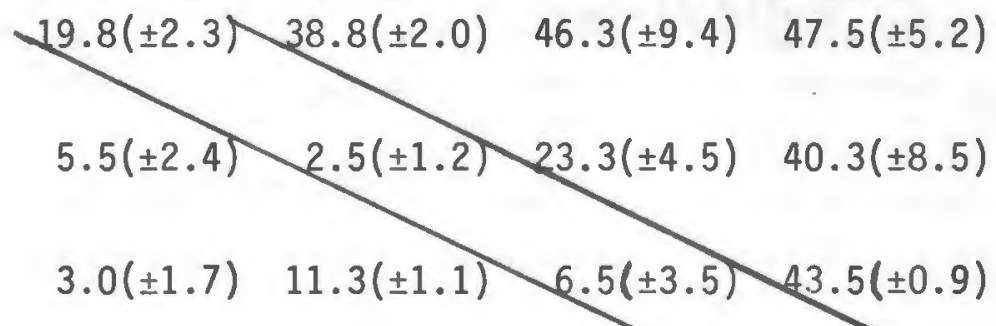

$2.8( \pm 1.7) \quad 8.0( \pm 4.5)$

Chemotactic Index $(b)$
Concentration of OM 4245

Below Filter

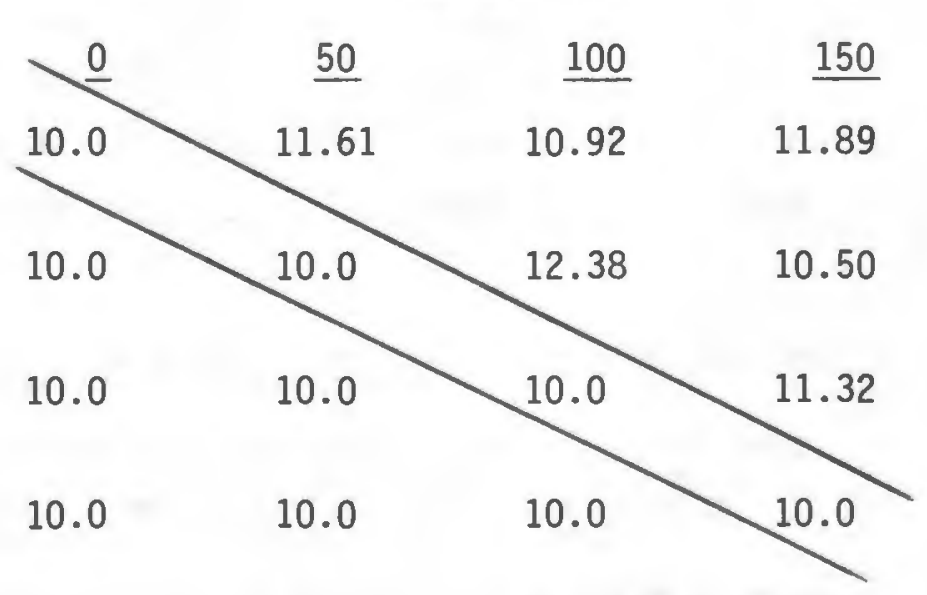

a) Values represent the mean ( \pm SEM) number of neutrophils per high power $(400 x)$ field [four high power fields were counted for duplicate Boyden chambers].

b) The values represent the average distance $(\mu \mathrm{m})$ traveled per neutrophil from the top of the filter toward the bottom. 
Table 2. Rabbit PMN Neutrophils Response to Bacteroides fragilis Cellular Components or Products in the Presence and Absence of Guinea Pig Complement

\begin{tabular}{|c|c|c|}
\hline $\begin{array}{l}\text { Addition to } \\
\text { Lower Compartment }\end{array}$ & $\begin{array}{l}\text { Chemotactic } \\
\text { PMN Neutrophils } / 4 \\
\text { H.P.F. (mean } \pm \text { SEM) }\end{array}$ & $\begin{array}{l}\text { Activity } \\
\text { Chemotactic (a) } \\
\text { Index }\end{array}$ \\
\hline None (HBSS) & $58 \pm 3.9$ & 10.0 \\
\hline Culture filtrate (CF) VPI $5383^{(\mathrm{C})}(50 \mu 1)^{(\mathrm{b})}$ & $257 \pm 4.4$ & 12.14 \\
\hline $\begin{array}{l}\text { Lipopolysaccharide (LPS) VPI } 9032 \\
(62.5 \mu \mathrm{g})\end{array}$ & $66 \pm 4.9$ & 11.17 \\
\hline Outer membrane (OM) VPI $2553(62.5 \mu \mathrm{g})$ & $62.5 \pm 7.0$ & 10.94 \\
\hline Outer membrane (OM) VPI $5383(62.5 \mu \mathrm{g})$ & $83 \pm 4.2$ & 11.20 \\
\hline Outer membrane (OM) VPI $9032(62.5 \mu \mathrm{g})$ & $88 \pm 19.3$ & 12.29 \\
\hline CF VPI $5383+$ Guinea pig comp. $\left(37^{\circ} \mathrm{C}\right)^{(\mathrm{b})}$ & $18.5 \pm 13.1$ & 10.0 \\
\hline LPS VPI $9032+$ Guinea pig comp. ${ }^{(\mathrm{c})}\left(37^{\circ} \mathrm{C}\right)$ & $75.8 \pm 14.4$ & 13.27 \\
\hline OM 2553 + Guinea pig comp. ${ }^{(\mathrm{c})}\left(37^{\circ} \mathrm{C}\right)$ & $53.3 \pm 6.4$ & 10.0 \\
\hline OM 5383 + Guinea pig comp. ${ }^{(\mathrm{c})}\left(37^{\circ} \mathrm{C}\right)$ & $24.3 \pm 1.4$ & 10.0 \\
\hline OM 9032 + Guinea pig comp. ${ }^{(\mathrm{C})}\left(37^{\circ} \mathrm{C}\right)$ & $10.0 \pm 7.1$ & 10.0 \\
\hline 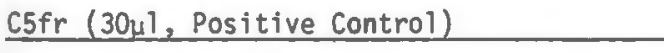 & $152 \pm 11.5$ & 13.56 \\
\hline
\end{tabular}

a) Chemotactic Index is the average distance $(\mu \mathrm{m})$ traveled per neutrophil from the top of the filter toward the bottom.

b) These were from another experiment having control values of $17.3 \pm 3.1$ PMN neutrophils/4 H.P.F. \pm SEM and 10.0 Chemotactic Index for no additions and $394 \pm 39.6$ PMN neutrophils/4 H.P.F. \pm SEM and 17.06 Chemotactic Index for $30 \mu 1$ of $\mathrm{C} 5 \mathrm{fr}$ (in 0.8 to $1 \mathrm{~m} 1 \mathrm{hBSS}$ ).

c) $1 \mathrm{ml}$ of culture filtrate or $1 \mathrm{ml}$ of HBSS containing $62.5 \mu \mathrm{g}$ OM or LPS was added to $1 \mathrm{ml}$ of guinea pig complement and incubated at $37^{\circ} \mathrm{C}$ for 30 minutes. 0.8 to $1.0 \mathrm{ml}$ of one of these mixtures was added to the lower compartment of the Boyden chambers. 
Table 3. Rabbit PMN Neutrophils Chemotactic Response to C5 Fragment in the Presence and Absence of Bacteroides fragilis VPI 5383 Cellular Components or Products

\begin{tabular}{|c|c|c|}
\hline dordition to & $\begin{array}{l}\text { Chemotact } \\
\text { PMN Neutrophils/4 } \\
\text { H.P.F. } \pm \text { SEM }\end{array}$ & $\begin{array}{l}\text { Activity } \\
\text { Chemotactic } \\
\text { Index }\end{array}$ \\
\hline None (HBSS) & $17.3 \pm 2.2$ & 10.0 \\
\hline $\operatorname{c5fr}(30 \mu 1)$ & $394 \pm 28.0$ & 17.06 \\
\hline Culture filtrate (CF) VPI $5383(50 \mu 1)$ & $257 \pm 4.4$ & 12.14 \\
\hline Outer membrane (OM) VPI $5383(62.5 \mu \mathrm{g})$ & $237 \pm 13.8$ & 12.83 \\
\hline CF VPI $5383+C 5 f r(a)$ & $313 \pm 23.4$ & 14.29 \\
\hline $25893+C 5 f r(a)$ & $301 \pm 49.8$ & 14.6 \\
\hline
\end{tabular}

a) One $\mathrm{ml}$ of CF or HBSS containing $(62.5 \mu \mathrm{g} / \mathrm{ml})$ OM was added to $1 \mathrm{ml}$ of HBSS containing $30 \mu 1$ of $\mathrm{C} 5 \mathrm{fr}$. This was incubated at $37^{\circ} \mathrm{C}$ for 30 minutes, then $0.8-1 \mathrm{ml}$ of the mixture was added to the lower compartment of Boyden chambers. 
Table 4. N-acetyl-B-glucosaminidase Activity(a) Released

From Cytochalasin B-treated Rabbit PMN Neutrophils in

Response to Cellular Components or Products of Bacteroides

Additions to Reaction Mixture(b)

$\Delta \mathrm{A}_{410^{ \pm S d}}$

None

$(0.587 \pm 0)$

C5fr (50 1 1, positive control)

$0.993 \pm 0$

Culture Filtrate VPI 2553

$0.093 \pm 0.004$

Culture Filtrate VPI 4245

$0.114 \pm 0.01$

Culture Filtrate VPI 5383

$0.080 \pm 0.005$

Lipopolysaccharide VPI 9032

$0.040 \pm 0.01$

Outer membrane VPI 2553

$0.043 \pm 0.12$

Outer membrane VPI 5383

$0.043 \pm 0.04$

membrane VPI 9032

$0.046 \pm 0.06$

a) The reaction mixture contained: $0.5 \mathrm{ml}$ of $4 \mathrm{mM}$ solution of $p$-nitro-

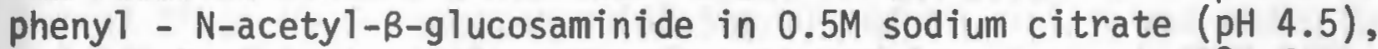
and $0.5 \mathrm{ml}$ of test sample. The mixture was incubated at $37{ }^{\circ} \mathrm{C}$ for one hour, then terminated by addition of $0.5 \mathrm{ml}$ of $0.4 \mathrm{M}$ glycine buffer ( $\mathrm{pH} 10.5$ ) and the absorbance at $410 \mathrm{~nm}$ was read in a spectrophotometer.

b) The reaction mixture contained: $0.5 \mathrm{ml}$ of cytochalasin B-treated rabbit PMN neutrophils ( $5 \times 10^{6}$ cells), and $0.05 \mathrm{ml}$ of sample (CF or HBSS containing $62.5 \mu \mathrm{g} / \mathrm{ml}$ of OM or LPS). The mixture was incubated for five minutes at $37^{\circ} \mathrm{C}$, centrifuged at $2000 \times \mathrm{g}$ for five minutes, and the supernatant was assayed for $\mathrm{N}$-acetyl- $\beta$-glucosaminidase. 
Table 5. N-acetyl-B-glucosaminidase Activity Released From Cytochalasin B-Treated Rabbit PMN Neutrophils in Response to Bacteroides Cellular Products or Components Pre-Incubated at $37^{\circ} \mathrm{C}$ with Guinea Pig Complement for 30 minutes $(a)$

Addition to Reaction Mixture

$\Delta A_{410} \pm S d$

None

$0.587 \pm 0$

C5fr (50ul, Positive Control)

$0.993 \pm 0$

Culture Filtrate VPI 2553

$1.044 \pm 0.045$

Culture Filtrate VPI 4245

$1.282 \pm 0.24$

Culture Filtrate VPI 5383

$1.251 \pm 0.29$

Lipopolysaccharide VPI 9032

$1.096 \pm 0.07$

Outer membrane VPI 2553

$1.473 \pm 0.06$

Outer membrane VPI 2553

$1.276 \pm 0.04$

\section{aembrane VPI 9032}

$1.219 \pm 0.04$

Refer to Table 4 for assay procedure.

a) $1 \mathrm{ml}$ of CF or HBSS containing $(62.5 \mu \mathrm{g} / \mathrm{ml})$ of OM or LPS was added to $1 \mathrm{ml}$ of guinea pig complement and incubated for 30 minutes at $37^{\circ} \mathrm{C}$, prior to adding $50 \mu 1$ of this mixture to the cytochalasin B-treated PMN neutrophils. 


\section{DISCUSSION}

The observations reported here indicate that both outer membranes and culture filtrates of Bacteroides fragilis (VPI 5383, VPI 9032, VPI 2553) and $\underline{B}$. vulgatus (VPI 4245) induced PMN neutrophil chemotaxis. Furthermore, when guinea pig serum complement was incubated with outer membranes or culture filtrates of $\underline{B}$. fragilis (VPI 2553, VPI 5383, VPI 9032) or $\underline{B}$. vulgatus (VPI 4245) or the lipopolysaccharide of $\underline{B}$. fragilis (VPI 9032), the release of $N$-acetyl-B-glucosaminidase from cytochalasin B-treated PMN neutrophils was induced.

In contrast, PMN neutrophil chemotaxis was markedly diminished When Bacteroides crude outer membrane or culture filtrates were preincubated (at $37^{\circ} \mathrm{C}$ for 30 minutes) with guinea pig serum complement. These findings suggest that an inhibitor of neutrophil chemotaxis may be generated upon interaction of Bacteroides outer membrane or sterile culture filtrates with guinea pig complement. The fact that this factor (or inhibitor of neutrophil chemotaxis) was able to increase enzyme release of PMN neutrophils; while at the same time inhibit chemotaxis, suggests that either different PMN neutrophil receptors were triggered or the neutrophil receptors responsible for chemotaxis inhibition and enzyme release are identical or situated in the same vicinity, such that once one receptor is triggered the other is also.

Casciato et al indicated that different metabolic pathways may be involved in neutrophil movement, depending upon the mechanism that produced the chemotactic factor (17). Whereas chemotaxis in response 
to factors produced by whole Staphylococcus aureus, Escherichia coli and B. fragilis suspended in plasma was depressed under anaerobic conditions, chemotaxis induced by factors generated from immune complexes suspended in plasma was identical under aerobic and anaerobic conditions (17). Hence, they suggested that suspension of bacteria in plasma might have produced an inhibitor of neutrophil chemotaxis. Indeed, inhibitors of chemotaxis produced by soluble products, purified Typhoid somatic cabohydrate (15), bacterial toxins liberated from $\underline{S}$. aureus (93) and Mostridium perfringens (97) have been demonstrated.

The factor produced when Bacteroides cellular components or products (outer membrane and culture filtrates) were incubated with guinea pig complement may have induced a shock effect on the neutrophils, resulting in inhibited locomotion or altered inflammatory response; mimicking the Leukopenia evidenced in the in vivo response to bacterial endotoxin. This possible relationship was previously discussed by Martin and Chaudhuri (15).

Previous studies dealing with interactions of synthetic peptides and neutrophils suggested that there may be a common receptor for chemotaxis, lysosomal enzyme secretion from neutrophils and phagocytosis (45, 70). Our findings do not necessarily contradict the previous studies; however, the data indicates that the two neutrophil functions, inhibited locomotion and enzyme release, may be triggered by the same factor generated upon incubation of Bacteroides outer membrane or culture filtrates with guinea pig serum complement.

This report demonstrates that Bacteroides LPS, outer membrane and culture filtrates possess low chemotactic activity and enzyme releasing 
effect on neutrophils in comparison with the $\mathrm{C} 5$ fragment. This agrees in part with earlier findings by Sveen and others who showed Bacteroides LPS possesses chemotaxigenic activity for leukocytes $(77,78)$. Our findings also support the report that the interaction of Bacteroides LPS with serum complement leads to increased neutrophil chemotaxis $(77,78)$; thus demonstrating Bacteroides LPS is cytotaxigenic. Our data showing that: (i) Bacteroides outer membrane and culture filtrates induce low level chemotaxis and enzyme release; and ( $i i)$ incubation of the same acteroides cellular components or products with guinea pig complement resulted in increased enzyme secretion and retarded neutrophil 1ocomotion, add credence to the suggestion that different receptors are involved in PMN neutrophil locomotion and enzyme release (in response to Bacteroides cellular components or products). Another possibility might be that the neutrophil receptor sites responsible for positive chemotaxis, inhibited chemotaxis, and enzyme release are topographically closely linked or identical.

Chemokinesis experiments demonstrated a requirement for Bacteroides cellular components or products to establish a concentration gradient across the Millipore membrane filter before neutrophil chemotaxis could take place. This indicates that the Bacteroides fellular components and products tested were truly chemotactic for neutrophils, and were not simply inducing random walk (chemokinesis) of the neutrophils. These findings agree with those of Casciato et al (17), Zigmond and Hirsch (100) and others who have demonstrated that a concentration gradient is required for neutrophil chemotaxis. Furthermore, according to these investigators, it is essential (in describing any substance as being 
Ahemotactic" on the basis of its ability to induce migration in Boyden chamber) to provide evidence that the substance is capable of inducing directed movement (70).

In this study, Bacteroides cellular components and products did not induce the release of lactate dehydrogenase (LDH). Lactate dehydrogenase is strictly a cytoplasmic, non-lysosomal, enzyme; therefore, it is a marker of cell viability $(34-36,99)$. The lack of release of the non-granular enzyme, lactate dehydrogenase, indicates that cell damage was not necessary for extracellular release of the granular enzyme N-

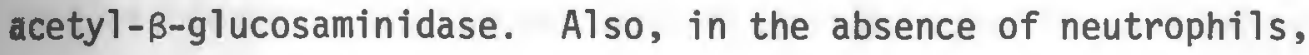

Dacteroides cellular components and products had no $\mathrm{N}$-acetyl- $\beta$-glucosaminidase activity.

When guinea pig serum complement was heat-inactivated $\left(55^{\circ} \mathrm{C}\right.$ for 30 minutes) and subsequently added to equal volumes of Bacteroides outer membrane or culture filtrates, neutrophil chemotaxis was still reduced and considerable enzyme release still occurred. This indicates the proinhibitor, or whatever factor it may be, that is produced when Bacteroides cellular components or products are incubated with serum complement may be heat stable.

Our results also indicated that when Bacteroides outer membrane or culture filtrates were incubated with purified C5 fragment, PMN neutrophil chemotaxis was decreased, relative to the response to the $\mathrm{C5}$ fragment alone. However, the same Bacteroides cellular components or products pre-incubated (at $37^{\circ} \mathrm{C}$ for 30 minutes) with guinea pig complement inhibited PMN neutrophil chemotaxis far more than when they were incubated with just the purified $\mathrm{C} 5$ fragment. This suggests that additional 
serum factors in guinea pig complement, which were absent from purified C5 fragment, may be necessary for initiating inhibition of neutrophil chemotaxis by Bacteroides culture filtrates and outer membrane.

Martin and Chaudhuri reported the only previous findings, that leakocyte migration was inhibited by gram negative bacterial components or products and they indicated that staphylococci and pneumococci were without effect (15). Bryant et al presumed that the inhibition of neutrophil migration produced by gram negative cellular components or products reported by Martin and Chaudhuri was because gram negative bacterial products contain smaller and more dispersable particles than gram positive bacterial products. These gram negative products, as presumed by Bryant et al, could be digested even in systems not designed to enhance cellparticle contact and thus lead to inhibition of neutrophil chemotaxis (15). This assumption appeared to be based on the technique used by Martin and Chaudhuri (15). However, the present study examined the interaction of Bacteroides cellular components and products with Boyden's technique (14). Our data clearly contradict assumptions made by Bryant et al and support the findings by Martin and Chaudhuri. Chemotaxis experiments with Boyden's technique are, according to Hard et al (85-91), Zigmond and Hirsch (100), Kreutzer and Fantone (22), and Becker et al (6-9), not only qualitative but also quantitative. This technique has proved to be the most widely used and accepted because of its reproducibility (6). However, it should be noted that many of these investigators presently employ computers for determination of chemotactic counts, due to the very tedious nature of counting chemotaxis slides. In this study manual counting was employed, hence it was usually necessary to have a blind reading. 
A relationship was shown between the amount of outer membrane of B. Eragilis and the chemotactic response of rabbit peritoneal neutrophils (Figure 1). Ward, Lepow, and Newman previously demonstrated a direct relationship between the amount of 48 hour culture filtrate from Type 3 acumococcus and neutrophil chemotaxis (91). The slope of their line was greatest at lower doses $(50 \mu 1$ and $100 \mu 1)$. The data in Figure 1, indicates that the sharpest rise in neutrophil chemotactic response to Bacteroides outer membrane was around $50-62 \mu \mathrm{g} / \mathrm{ml}$. This was the reason why $62.5 \mu \mathrm{g} / \mathrm{ml}$ of either outer membrane or LPS were used routinely for the chemotaxis and enzyme release experiments.

The incidence of anaerobic infections caused by gram negative bacteria has increased in recent years and $\underline{B}$. fragilis is the organism most frequently encountered in these human infections $(29,39-44,53)$. Bacteroides may act synergistically with other obligate anaerobes [eg. awsobacterium necrophorum $(29,31)$ ] in mixed infections to inhibit Thagocytosis and killing of other bacteria; which, when present alone may not be virulent $(29,31,38)$. Ingham et al found that the inhibitory activity of these obligately anaerobic Bacteroides is due solely to an interaction with serum (38). Our data agree with his findings and also support his suggestion that there is need for study of the serum moiety or moieties affected by Bacteroides. The factor or effect produced by incubating Bacteroides cellular components or products (outer membrane and culture filtrates) with serum complement, behaves similarly to the neutrophil-immobilizing factor described by Goetz and Austen (27). The Geutrophil-immobilizing factor is a low molecular weight, heat-stable substance liberated from neutrophils during maximum phagocytosis. This 
immobilizing factor which inhibits neutrophil movement gives high yields of Tysosomal enzymes (27).

The high frequency of $\underline{B}$. fragilis in clinical infections (31) has been postulated to be due to the resistance of most strains of $\underline{B}$. fragilis to antibiotics $(29,31,53)$. Tissue damage occurs when neutrophils release tissue destructive lysosomal enzymes into their surrounding environment $(34,99)$. These data indicate that in the presence of guinea pig serum complement, enzyme release is increased and neutrophil locomotion is inhibited; interfering with phagocytosis. These findings coupled with the resistance of Bacteroides to antibiotics may well account for the fact that a combination of antibiotic therapy and surgical drainage of Bacteroides abscesses (71) is usually required for eradication of these infections. Furthermore, it is suggested that mixed flora infections due in part to Bacteroides may be attributed to the production of PMN neutrophi1 inhibitor(s); since the Bacteroides products from different strains were capable of producing similar neutrophilic responses. Little is known about cellular or whole body interaction with factors produced by bacteria $(91,96)$. Two neutrophil-associated serine esterases, one present as an active esterase the other as a proesterase, are required for the interaction of complement-derived factor with neutrophile to cause chemotaxis (91). However, it is still not clear whether these same esterases are required for the neutrophils to respond to bacterial chemotactic factors.

Bacteroides fragilis produces many extracellular substances and the full array of extracellular enzymes produced by the genus Bacteroides is not known (68). Rudek and Haque have shown that Bacteroides produce 
fibrinolysin, penicillinase, lysozyme, lecithinase, deoxyribonuclease, phosphatase, protease, gelatinase, lipase, elastase, chondroitin sulphatase and hyaluronidase (68). The roles of these enzymes in acteroides infectious processes is uncertain. In other bacteria (eg. staphylococci), elastase, hyaluronidase and chondroitin sulfatase have been suggested as invasive or spreading factors in the infectious process (68).

Further study concerning the response generated when serum complement and Bacteroides outer membrane or culture filtrates interact is needed. One should also examine the role played by extracellular enzymes produced by Bacteroides. The host defense mechanism(s) and the pathogenicity of the infecting bacteria are important in bacterial infections; hence, further study of the interaction of Bacteroides purified products or cellular components may give a better understanding to the role acteroides plays in human infections. 


\section{APPENDIX A}

\section{Salts Solution (37a)}

Add the following as described:

$\begin{array}{lr}\mathrm{CaCl}_{2} \text { (anhydrous) } & 0.2 \mathrm{~g} \\ \mathrm{MgSO}_{4} \text { (anhydrous) } & 0.2 \mathrm{~g} \\ \mathrm{~K}_{2} \mathrm{HPO}_{4} & 1.0 \mathrm{~g} \\ \mathrm{KH}_{2} \mathrm{PO}_{4} & 1.0 \mathrm{~g} \\ \mathrm{NaHCO}_{3} & 10.0 \mathrm{~g} \\ \mathrm{NaCl} & 2.0 \mathrm{~g}\end{array}$

Mix $\mathrm{CaCl}_{2}$ and $\mathrm{MgSO}_{4}$ in $300 \mathrm{ml}$ distilled water until dissolved. Add $500 \mathrm{ml}$ distilled water and while stirring, slowly add the remaining salts. Continue swirling until all these salts are dissolved. Add $200 \mathrm{ml}$ distilled water, $\mathrm{mix}$, and store at $4^{\circ} \mathrm{C}$. 


\section{APPENDIX B}

\section{Pre-Reduced Chopped Meat Broth (37a)}

The following are added:

Ground beef (fat free)

$500 \mathrm{~g}$

distilled water

$1000 \mathrm{ml}$

1 Normal $\mathrm{NaOH}$

$25 \mathrm{ml}$

Remove fat and connective tissue from lean beef before grinding. Mix meat, water and $\mathrm{NaOH}$ and bring this to a boil while stirring. Cool media to room temperature and then skim the fat off the surface. Filter the mixture retaining both meat particles and the filtrate. To the filtrate add sufficient water to restore it to the one liter original volume.

To this filtrate add:

Trypticase $30 \mathrm{~g}$

Yeast Extract $5 \mathrm{~g}$

Potassium Phosphate $5 g$

resazurin solution

$4 \mathrm{ml}$ (dissolve

$25 \mathrm{mg}$ of resazurin powder in $100 \mathrm{ml}$ distilled water).

Boil the filtrate and $\mathrm{coOl}$ under $\mathrm{O}_{2}$-free $\mathrm{CO}_{2}$, then add $0.5 \mathrm{~g}$ cysteine-HCl and $10.0 \mathrm{ml}$ hemin solution (dissolve $50 \mathrm{mg}$ of hemin in $1 \mathrm{ml}$ of $1 \mathrm{~N} \mathrm{NaOH}$, add $99 \mathrm{ml}$ of distilled water and autoclave at $121^{\circ} \mathrm{C}$ for 15 minutes). Adjust $\mathrm{pH}$ of medium to neutrality. Under oxygen-free $\mathrm{CO}_{2}$, dispense $7 \mathrm{ml}$ of broth 
into tubes containing meat particles (use one part meat particles to four to five parts fluid). Stopper tubes and autoclave in press at $121^{\circ} \mathrm{C}$ for 15 minutes. 


\section{APPENDIX C}

\section{Hank's Balanced Salts Solution (HBSS) (Flow Modified)}

\section{Hank's $1 X$ Concentrated (22).}

Hank's 10X concentrated ${ }^{a}$

$50.0 \mathrm{ml}$

Demineralized distilled water

$500.0 \mathrm{ml}$

IM Tris

(pH 7.3)

$13.75 \mathrm{~m} 1$

1.1M Calcium Chloride (anhydrous)

$0.825 \mathrm{ml}$

$0.4 \mathrm{M} \mathrm{MgSO}_{4}$

$1.0 \mathrm{~m} 1$

Glucose

$1.1 \mathrm{~g}$

$1.4 \%$ (wt/vol) $\mathrm{NaHCO}_{3}$

$50.0 \mathrm{~m} 7$

Adjusted to $\mathrm{pH} 7.2-7.4$

\section{'Hank's 10X Concentrated Buffer}

$\mathrm{NaCl}$

$40.0 \mathrm{~g}$

KC1

$2.0 \mathrm{~g}$

$\mathrm{Na}_{2} \mathrm{HPO}_{4}$

$0.5 \mathrm{~g}$

$\mathrm{KH}_{2} \mathrm{PO}_{4}$

$0.5 \mathrm{~g}$

Demineralized distilled water

$500.0 \mathrm{ml}$ 


\section{LITERATURE CITED}

1. Allison, F., Jr., Lancaster, M. G., Crosthwaite, J. L., 1963. Studies on the Pathogenesis of Acute Inflammation v. An Assessment of Factors That Influence in vitro the Phagocytic and Adhesive Properties of Leukocytes Obtained from Rabbit Peritoneal Exudate. J. Exp. Med. 43: 777-793.

2. Avila, J. L., and Convit, J., 1973. Studies on Human Polymorphonuclear Leukocyte Enzymes Assay of Acid Hydrolases and Other Enzymes. Biochem et Biophys. Acta. 293: 397-408.

3. Ayoub, E. M., and McCarthy, M., 1968. Intraphagocytic B-N-AcetylGlucosaminidase. Properties of the Enzyme and Its Activity on Group A Streptococcus Carbohydrate in Comparison with A Soil Bacillus Enzyme. ‥ Exp. Med. 127: 833-851.

4. Bainton, D. F., and Fraquhar, M. G., 1968. Differences of Enzyme Content of Azurophil and Specific Granules of Polymorphonuclear Leukocytes. II. Cytochemistry and Electron Microscopy of Bone Marrow Cells. J. Cell Biol. 39: 299-317.

5. Baker, L. A., Cambell, P. A., and Hollister, J. R., 1977. Chemotaxigenes is and Complement Fixation by Listeria monocytogenes Cel1 Wall Fractions. J. Immunol. 119: 1723-1726.

6. Baum, J., Mowat, A. G., and Kirk, J. A., 1971. A Simplified Method for the Measurement of Chemotaxis of Polymorphonuclear Leukocytes from Human Blood. ‥ Lab. Clin. Med. 77: 501-509.

7. Becker, E. L., 1971. The Relationship of the Chemotactic Behavior of the Complement-Derived Factors, C3a, C5a and C567 and a Bacterial Chemotactic Factor to Their Ability to Activate the Proesterase 1 of Rabbit Polymorphonuclear Leukocytes. J. Exp. Med. 135: 376-387.

8. Becker. E. L., and Showel1, H. J., 1974. The Ability of Chemotactic Factors to Induce Lysosomal Enzyme Release. II. Mechanism of Re7ease. J. Immunol. 112: 2055-2062.

9. Becker. E. L., Showell, H. J., Henson, P. M., and Hsu, L. S., 1974. The Ability of Chemotactic Factors to Induce Lysosomal Enzyme Release. I. The Characteristics of the Release, the Importance of the Surface and the Relation of Enzyme Release to Chemotactic Responsiveness. J. Immunol. 112: 2047-2054. 
10. Bjornson, A. B., and Bjornson, S. H., 1978. Participation of Immunoglobulin and the Alternative Complement Pathway in Opsonization of Bacteroides fragilis and Bacteroides thetaiotaomicron. J. Infect. Dis. 138: 351-358.

11. Boehringer Mannheim Co., 1973. In Biochemical Information Boehringer and Mannheim Co., Biochemica West Germany.

12. Borel, J. F., Keller, H. M., and Sorkin, E., 1969. Studies on Chemotaxis. XI. Effect on Neutrophils of Lysosomal and other Subcellular Fractions from Leukocytes. Int. Arch. Allergy 35: 194-205.

13. Boxer, L. A., Yoder, M., Bonsib, S., Schmidt, M., Ito, P., Jersild, R., and Baehner, R. L., 1979. Effects of a Chemotactic Factor, Nformylmethionyl peptide, on Adherence, Superoxide anion Generation, Phagocytosis, and Microtubule Assembly of Human Polymorphonuclear Leukocytes. J. Lab. Clin. Med. 93: 506-513:

14. Boyden, S., 1962. The Chemotactic Effect of Mixtures of Antibody and Antigen on Polymorphonuclear Leukocytes. J. Exp. Med. 115: 453-466.

15. Bryant, R. E., DesPrez, R. M., Vanway, M. H., and Rogers, D. E., 1966. Studies on Human Leukocyte Motility. Effects of Alterations in pH. Electrolyte Concentration and Phagocytosis on Leukocyte Adhesiveness and Aggregation. J. Exp. Med. 124: 483-499.

16. Burt, S., Meldrum, S., Woods, D. R., and Jones, D. T., 1978. Colonial Variation, Capsule Formation, and Bacteriophage Resistance in Bacteroides thetaiotaomicron. Appl. Environ. Microbiol. 35: $439-443$.

17. Casciato, D. A., Goldberg, L. S., and Bluestone, R., 1978. Polymorphonuclear Neutrophil Chemotaxis Under Aerobic and Anaerobic Conditions. Infect. Immun. 21: 381-386.

18. Clark, R. A., Page, R. C., and Wilde, G., 1977. Defective Neutrophil Chemotaxis in Juvenile Periodontitis. Infect. Immun. 18: 694-700.

19. Cohn, Z. A., and Hirsch, J. G., 1961. The Isolation and Properties of the Specific Cytoplasmic Granules of Rabbit Polymorphonuclear Leukocytes. ‥ Exp. Med. 112: 983-1002.

20. Corrigan, J. J., and Be11, B. M., 1971. Comparison Between the Polymyxins and Gentamicin in Preventing Endotoxin-Induced Intravascular Coagulation and Leukopenia. Infect. Immun. 4: 563-566.

21. Easmon, C. S. F., and Glynn, A. A., 1976. Comparison of Subcutaneous and Intraperitoneal Staphylococcal Infections in Normal and Complement Deficient Mice. Infect. Immun. 13: 399-406. 
22. Fantone, J., Senior, R. M., Kreutzer, D. L., Jones, M., and Ward, P. A., 1979. Biochemical Quantitation of the Chemotactic Factor Inactivator Activity in Human Serum. J. Lab. Clin. Med. 93: 17-24.

23. Finegold, S. M., 1977. In Anaerobic Bacteria In Human Disease. Academic Press Inc., New York.

24. Frei, P. C., Hermanovicz, A. J., and Pecound, A., 1978. Chemotaxis of Human Polymorphonuclears in Vitro. V. Role of Nonsegmented Neutrophils and of the Experimental Conditions in the Impairment of Chemotaxis Observed During Bacterial Infections. J. Lab. Clin. Med. 92: 577-583.

25. Gallin, J. I., and Quie, P. G., 1978. In Leukocyte Chemotaxis: Methods, Physiology and Chemical Implications. Raven Press, New York.

26. Gallin, J. I., and Rosenthal, A. S., 1974. The Regulatory Role of Divalent cations in Human Granulocyte Chemotaxis. Evidence for Association Between Calcium Exchanges and Microtubule Assembly. J. Cell Biol. 62: 594-609.

27. Goetz, E. J., and Austen, K. F., 1972. A Neutrophil Immobilizing Factor Derived from Human Leukocytes. I. Generation and Partial Characterization. J. Exp. Med. 136: 1564-1680.

28. Goldstein, I. M., Wunschmann, B., Astrup, T., and Henderson, E. S., 1971. Effects of Endotoxin on the Fibrinolytic Activity of Normal Human Leukocytes. Blood 37: 447-453.

29. Gorbach, S. L., and Bartlett, J. G., 1974. Medical Progress. Anaerobic Infections. N. Engl. J. Med. 290: 1177-1184, 1237-1245.

30. Greisman, S. E., and Hornick, R. B., 1972. Cellular Inflammation Responses of Man to Bacterial Endotoxin: A Comparison with PPD and other Bacterial Antigens. ‥ Immunol. 109: 1210-1222.

31. Hackman, A. S., and Wilkins, T. D., 1976. Influence of Penicillinase Production by Strains of Bacteroides melaninogenicus and Bacteroides oralis on Penicillin Therapy of an Experimental Mixed Anaerobic Infection of Mice. Arch. Oral Biol. 21: 385-389.

32. Hausman, M. S., Snyderman, R., and Mergenhagen, S. E., 1972. Humoral Mediators of Chemotaxis of Mononuclear Leukocytes. ‥ Infect. Dis. 125: 595-602.

33. Henson, P. M., 1971. The Immunologic Release of Constituents from Neutrophil Leukocytes. I. Role of Antibody and Complement on Nonphagocytosable Surfaces or Phagocytosable Particles. J. Immunol. 107: 1535-1546. 
34. Henson, P. M., 1971. The Immunologic Release of Constituents from Neutrophil Leukocytes. II. Mechanisms of Release During Phagocytosis, and Adherence to Nonphagocytosable Surfaces. J. Immunol. 107: $1547-1557$.

35. Henson, P. M., and Oades, Z. G., 1973. Enhancement of Immunologically Induced Granule Exocytosis from Neutrophils by Cytochalasin B. J. Immunol. 110: 290-293.

36. Henson, P. M., Zanolari, B., Schwartzman, N. A., and Hong, S. R., 1978. Intracellular Control of Human Neutrophil Secretion. I. C5a-induced Stimulus-specific Desensitization and the Effects of Cytochalasin B. J. Immunol. 121: 851-855.

37. Hofstad, T., and Kristofferson, T., 1970. Chemical Characteristics of Endotoxin from Bacteroides fragil is NCTC 9343. J. Gen. Microbiol. 61: 15-19.

37a. Holdeman, L. V., Cato, E. P., and Moore, W. E. C. (ed.) 1977. Media: preparation and pre-reduced media, p. 141-148 in Anaerobe Laboratory Manual, 4th ed. V. P. I. Anaerobe Laboratory, Virginia Polytechnic Institute and State University, Blacksburg, Virginia.

38. Ingham, H. R., Sisson, R. P., Tharagonnet, D., Selkon, J. B., and Codd, A. A., 1977. Inhibition of Phagocytosis in vitro by 0 bi igate Anaerobes. Lancet 2: 1252-1254.

39. Kasper, D. L., 1976. The Polysaccharide Capsule of Bacteroides fragilis Subspecies fragilis: Immunochemical and Morphologic Definition. J. Infect. Dis. 133: 79-87.

40. Kasper, D. L., 1976. Chemical and Biological Characterization of the Lipolysaccharide of Bacteroides fragilis subspecies fragilis. J. Infect. Dis. 134: 59-66.

41. Kasper, D. L., Hayes, M. E., Reinapp, B. G., Craft, F. O., Onderdonk, A. B., and Polk, B. F., 1977. Isolation and Identification of Encapsulated Strains of Bacteroides fragilis. J. Infect. Dis. 136: 75-81.

42. Kasper, D. L., Onderdonk, A. B., and Bartlett, J. G., 1977. Quantitative Determination of Antibody Response to the Capsular Polysaccharide of Bacteroides fragilis in Animal Model of Intraabdominal Abscess Formation. J. Infect. Dis. 136: 789-795.

43. Kasper, D. L., and Seiler, M. W., 1975. Immunochemical Characterization of the Outer membrane Complex of Bacteroides fragilis subspecies fragilis. ‥ Infect. Dis. 132: 440-450.

44. Kasper, D. L., Onderdonk, A. B., Crabb, J., and Bartlett, J. G., 1979. Protective Efficacy of Immunization with Capsular Antigen Against Experimental Infection with Bacteroides fragilis. J. Infect. Dis. 140: 724-731. 
45. Kay, N. E., Bumol, T. F., and Douglas, S. D., 1978. Effect of Phagocytosis and Fc receptor Occupancy on complement-dependent Neutrophil Chemotaxis. J. Clin. Med. 91: 850-856.

46. Keller, H. U., and Sorkin, E., 1967. Studies on Chemotaxis. V. On the Chemotactic Effect of Bacteria. Int. Arch. Allergy 31: 505-517.

47. Keller, H. U., and Sorkin, E., 1967. Studies on Chemotaxis. VI. Specific Chemotaxis in Rabbit Polymorphonuclear Leukocytes and Mononuclear Cells. Int. Arch. Allergy 31: 575-586.

48. Lay, W. H., and Nussenzweig, V., 1968. Receptors for Complement on Leukocytes. ‥ Exp. Med. 128: 991-1007.

49. Leffel, M. S., and Spitznagel, J. K., 1974. Intracellular and Extracellular Degranulation of Human Azurophil and Specific Granules Induced by Immune Complexes. Infect. Immun. 10: 1241-1249.

50. Leffel, M. S., and Spitznagel, J. K., 1975. Fate of Human Lactoferrin and Myeloperoxidase in Phagocytizing Human Neutrophils: Effects of Immunoglobulin $G$ subclasses and Immune Complexes Coated on Latex Beads. Infect. Immun. 12: 813-820.

51. Lehmeyer, J. E., Snyderman, R., and Johnston, R. B., Jr., 1979. Stimulation of Neutrophil Oxidative Metabolism by Chemotactic Peptides: Influence of Calcium ion Concentration and Cytochalas in $B$ and Comparison with Stimulation by Phorbol Myristate Acetate. Blood 54: 35-45.

52. Lerner, G. R., Goldstein, R., Cummings, G., 1971. Stimulation of Human Leukocyte Thromboplastic Activity by Endotoxin. Proc. Soc. Exp. Biol. Med. 138: 145-148.

53. Lindberg, A. A., Berthold, P., Nord, C. E., and Weintraub, A., 1979. Encapsulated Strains of Bacteroides fragilis in Clinical Specimens. Med. Microbiol. Immunol. 167: 29-36.

54. Mande11, G. L., 1974. Bactericidal Activity of Aerobic and Anaerobic Polymorphonuclear Neutrophils. Infect. Immun. 9: 337341.

55. Medicus, R. G., Schreiber, R. D., Gotze, 0., and Muller-Eberhard, H. J., 1976. A Molecular Concent of the Properdin Pathway. Proc. Nat. Acad. Sci. USA 73: 612-616.

56. Mega, T., Ikenaka, T., and Matsushima, Y., 1969. Studies on Nacetyl- $\beta-D-g$ lucosaminidase of Aspergillus Oryzae. I. Purification and Characterization of $\mathrm{N}$-acety $\overline{1-\beta-D-g 7 u c o s i a m i n i d a s e ~ o b t a i n e d ~ f r o m ~}$ Takadiastase. J. Biochem. 68: 109-117. 
57. Miller, M. E., 1973. A New Familial Defect of Neutrophil Movement. ․ Lab. Clin. Med. 82: 1-8.

58. Miller, T. E., 1969. Killing and Lysis of Gram-negative Bacteria Through the Synergistic Effect of Hydrogen Peroxide, Ascorbic Acid and Lysozyme. J. Bacteriol. 98: 949-955.

59. Moeller, G. R., Terry, L., and Snyderman. R., 1978. The Inflammatory Response and Resistance to Endotoxin in Mice. ‥ Immunol. 120: $116-123$.

60. Mowat, G. A., and Baum, J., 1971. Polymorphonuclear Leukocyte Chemotaxis in Patients with Bacterial Infections. Br. Med. $\underline{J}$. 3: 617-619.

61. Nakagama; S., Kumin, S., Fox, D., and Nitowsky, H. M., 1978. Human Hexosaminidase Isoenzymes. III. Distribution and Activity of Isoenzymes in Peripheral Blood Leukocytes and Platelets. $\underline{J}$. Clin. Med. 91: 922-928.

62. Onderdonk, A. B., Kasper, D. L., Cisneros, R. L., and Bartlett, J. G., 1977. The Capsular Polysaccharide of Bacteroides fragilis as Virulence Factor. Comparison of the Pathogenic Potential of Encapsulated and Unencapsulated Strains. ‥ Infect. Dis. 136: 82-89.

63. Onderdonk, A. B., Moon, N. E., Kasper, D. L., and Bartlett, J. G., 1978. Adherence of Bacteroides in vivo. Infect. Immun. 19: 1083-1087.

64. Peterson, P. K., Verhoef, J., Sabath, L. D., and Quie, P. G., 1976. Extracellular and Bacterial Factors Influencing Staphyloccoccal Phagocytosis and Killing by Human Polymorphonuclear Leukocytes. Infect. Immun. 14: 496-501.

65. Price, R. G., and Dance, N., 1972. The Demonstration of Multiple Heat Stable Forms of $\mathrm{N}$-acetyl- $\beta$-glucosaminidase in Normal Human Serum. Biochem Biophys. Acta 271: 145-153.

66. Quie, P. G., White, J. G., Holmes, B., and Good, R. A., 1967. In vitro Bactericidal Capacity of Human Polymorphonuclear Leukocytes: Diminished Activity in Chronic Granulomatous Disease of Childhood. J. Clin. Invest. 46: 668-679.

67. Rietsche1, T. E., Galanos, C., Tanaka, A., Ruschmann, E., Luderitz, 0., and Westphal, 0., 1971. Biological Activities of Chemically Modified Endotoxins. Eur. J. Biochem. 22: 218-224.

68. Rudek, W., and Haque, R., 1976. Extracellular Enzymes of the Genus Bacteroides. J. Clin. Microbiol. 4: 458-460. 
69. Shah, H. N., Williams, R. A. D., Bowden, G. H., and Hardie, J. M., 1976. Comparison of the Biochemical Properties of Bacteroides melaninogenicus from Human Dental Plaque and Other Sites. J. Appl. Bacteriol. 41: 473-492.

70. Showel1, H. J., Freer, R. J., Zigmond, S. H., Schiffman, E., Aswanikumar, S., Corcoran, B., and Becker, E. L., 1976. The Structure-Activity Relationships of Synthetic Peptides and Chemotactic Factors and Inducers of Lysosomal Enzyme Secretion for Neutrophils. J. Exp. Med. 143: 1154-1169.

71. Smith, L. D. S., 1975. The Pathogenic Anaerobic Bacteria. Charles C. Thomas, Publisher, Springfield, Illinois.

72. Snyderman, R., Phillips, J., and Mergenhagen, S. E., 1970. Polymorphonuclear Leukocyte Chemotactic Activity in Rabbit Serum and Guinea Pig Serum Treated with Immune Complexes: Evidence for C5a as the Major Chemotactic Factor. Infect. Immun. 1: 521-525.

73. Snyderman, R., Philips, J. K., and Mergenhagen, S. E., 1971. Biological Activity of Complement in vivo. Role of $\mathrm{C}_{5}$ in the Accumulation of Polymorphonuclear Leukocytes in Inflammatory Exudates. ‥ Exp. Med. 134: 1131-1143.

74. Snyderman, R., Shin, H. S., and Dannenberg, A. M., Jr., 1972. Macrophage Proteinase and Inflammation: The Production of Chemotactic Activity from the Fifth Component of Complement by Macrophage Proteinase. J. Immunol. 109: 896-898.

75. Sperry, J. F., Appleman, M. D., and Wilkins, T. D., 1977. Requirement of Heme for Growth of Bacteroides fragilis. Appl. Environ. Microbiol. 34: 386-390.

76. Spitznagel, J. K., Dalldorf, F. G., Leffel, M. S., Folds, J. D., Welsh, I. R. H., Cooney, M. H., and Martin, L. E., 1974. Character of Azurophil and Specific Granules Purified from Human Polymorphonuclear Leukocytes. Lab. Invest. 30: 774-785.

77. Sveen, K., 1977. Rabbit Polymorphonuclear Leukocyte Migration in vivo in Response to Lipopolysaccharides from Bacteroides, Fusobacterium and Veillonella. Acta. Path. Microbiol. Scand. Sect. B. 85: 381-387.

78. Sveen, K., 1978. Rabbit Polymorphonuclear Leukocyte Chemotactic Factor Generated in vivo by Bacteroides fragilis Lipopolysaccharide. Acta. Path. Microbiol. Scand. Sect. B. 86: 229-236, 237-245.

79. Taichman, N. S., Pruzanski, W., and Ranadive, N. S., 1972. Release of Intracellular Constituents from Rabbit Polymorphonuclear Leukocytes Exposed to Soluble and Insoluble Immune Complexes. Int. Arch. Allergy 43: $182-195$. 
80. Taichman, N. S., Tsai, C., Baehni, P. C., Stoller, N., and McArthur, W. P., 1977. Interaction of Inflammatory Cells and Oral Microorganisms. IV. In vitro Release of Lysosomal Constituents from Polymorphonuclear Leukocytes Exposed to Supragingival and subgingival Bacterial Plaque. Infect. Immun. 16: 1013-1023.

81. Tempel, T. R., Snyderman, R., Jordan, H. V., and Mergenhagen, S. E., 1970. Factors from Saliva and Oral Bacteria, Chemotactic for Polymorphonuclear Leukocytes: Their Possible Role in Gingival Inflammation. $\underline{\mathrm{J}}$. Periodont. 41: 71-80.

82. Thomas, L., 1964. Possible Role of Leukocyte Granules in Shwartzman and Arthus Reactions. Proc. Soc. Exp. Biol. Med. 115: 235-240.

83. Ward, P. A., 1966. The Chemosuppression of Chemotaxis. J. Exp. Med. 124: 209-226.

84. Ward, P. A., 1967. A Plasmin-Split Fragment of C'3 as a New Chemotactic Factor. J. Exp. Med. 126: 189-206.

85. Ward, P. A., 1974. Leukotaxis and Leukotactic Disorders. Am. J. Pathol. 77: 521-533.

86. Ward, P. A., and Becker, E. L., 1968. The Deactivation of Rabbit Neutrophils by Chemotactic Factor and the Nature of the Activatable Esterase. J. Exp. Med. 127: 693:709.

87. Ward, P. A., and Cochrane, C. G., 1965. Bound Complement and Immunologic Injury of Blood. J. Expt. Med. 121: 215-233.

88. Ward, P. A., Cochrane, C. G., and Muller-Eberhard, H. J., 1965. The Role of Complement in Chemotaxis of Leukocytes in vitro. J. Exp. Med. 122: 327-347.

89. Ward, P. A., and Hil1, J. H., 1970. C5 Chemotactic Fragments Produced by an Enzyme in Lysosomal Granules of Neutrophils. J. Immunol. 104: $535-543$.

90. Ward, P. A., and Hill, J. H., 1972. Biologic Role of Complement Products. Complement-derived Leukotactic Activity Extractable from Lesions of Immunologic Vasculitis. ‥ Immunol. 108: 1137-1145.

91. Ward, P. A., Lepow, I. H., and Newman, L. J., 1968. Bacterial Factors Chemotactic for Polymorphonuclear Leukocytes. Am. $\underline{\mathrm{J}}$. Pathol. 52: 725-736.

92. Weissman, G., 1974. Mediators of Inflammation. Plenum Press; New York.

93. Weksler, B. B., and Hill, M. J., 1969. Inhibition of Leukocyte Migration by a Staphylococcal Factor. J. Bacteriol. 98: 1030-1035. 
94. Welsh, I. R. H., and Spitznagel, J. K., 1971. Distribution of Lysosomal Enzymes, Cationic Proteins, and Bactericidal Substances in Subcellular Fractions of Human Polymorphonuclear Leukocytes. Infect. Immun. 4: 97-102.

95. West, B. C., Rosenthal, A. S., Gelb, N. A., and Kimball, H. R., 1974. Separation and Characterization of Human Neutrophil Granules. Am. J. Pathol. 77: 41-61.

96. Wilkinson, P. C., 1974. In Chemotaxis And Inflammation. Logman, Inc.; New York.

97. Wilkinson, P. C., 1976. Inhibition of Leukocyte Locomotion and Chemotaxis by Lipid-Specific Bacterial Toxins. Nature. 255: 485-487.

98. Woollen, J. W., Heyworth, R., and Walker, P. G., 1961. Studies on Glucosaminidase 3. Testicular N-acetyl-B-glucosaminidase and Nacetyl- $\beta$-galactosaminidase. Biochem. ․ 78: 111-116.

99. Wright, G. D., and Malawista, S. E., 1972. The Mobilization and Extracellular Release of Granular Enzymes from Human Leukocytes During Phagocytosis. ‥ Cell. Biol. 53: 788-797.

100. Zigmond, S. H., and Hirsch, J. G., 1973. Leukocyte Locomotion and Chemotaxis. New Methods for Evaluation, and Demonstration of a Cell-derived Chemotactic Factor. J. Exp. Med. 137: 387-410.

101. Zurier, R. B., Hoffstein, S., and Weissman, G., 1973. Cytochalasin B: Effect on Lysosomal Enzyme Release from Human Leukocytes. Proc. Nat. Acad. Sci. USA 70: 844-848. 